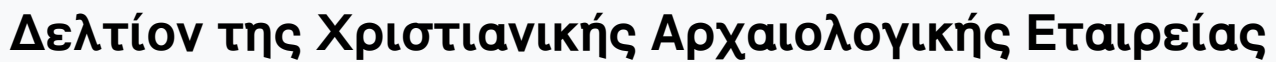

Tóp. 19 (1997)

$\Delta \varepsilon \lambda$ Tíov XAE 19 (1996-1997), Пعрі́обоৎ $\Delta^{\prime}$

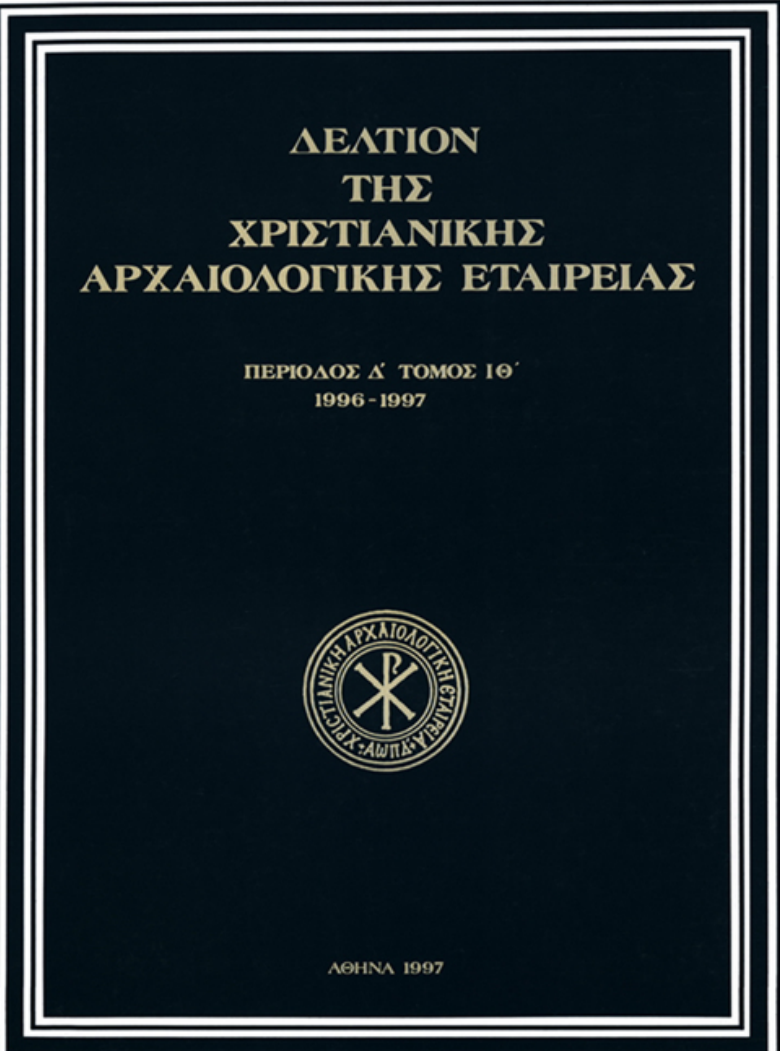

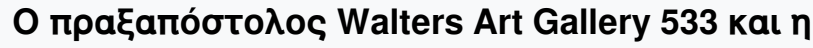

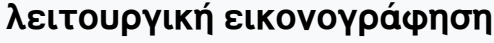

Jeffrey C. ANDERSON

doi: $\underline{10.12681 / \text { dchae. } 1161}$

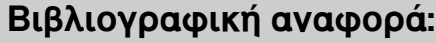

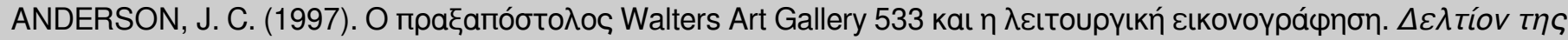

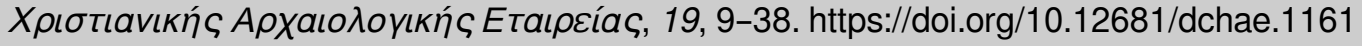




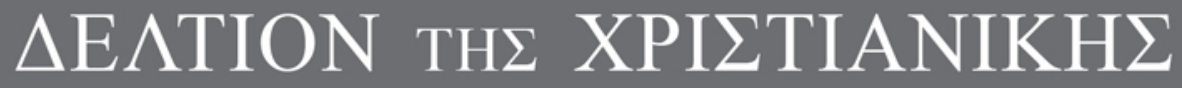 APXAIO $\Lambda$ OГIKH $\Sigma$ ETAIPEIA $\Sigma$}

The Walters Praxapostolos and Liturgical Illustration

Jeffrey ANDERSON

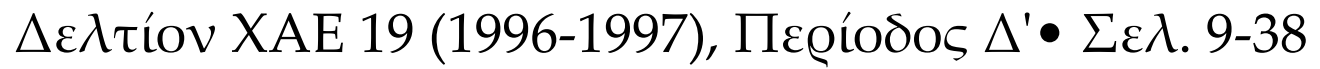

A@HNA 1997 
Jeffrey C. Anderson

\section{THE WALTERS PRAXAPOSTOLOS AND LITURGICAL ILLUSTRATION}

$\mathrm{D}$ uring the first half of the eleventh century Byzantine illuminators of Constantinople effectively joined rich methods of book ornament with an abstract style of figure painting. The result was a manner of illustration that matched both the scale of the book and the flatness of the written page. On occasion an illuminator might create a suite of images recalling the aristocratic ideal of ninth-and tenth-century painting; the Dumbarton Oaks Psalter-New Testament, Paris, gr. 64 and the Gospels of John II are three examples ${ }^{1}$. Otherwise, the approach was rooted in a vision of shallow space and limited corporeality; often, remarkably flat figures pose against unpainted vellum. The historical record favors an association of the abstract manner with the Studios monastery and eleventh-century works like the Paris Gospels (gr. 74), the Theodore and Barberini psalters (fig. 14) ${ }^{2}$. Although undoubtedly a force, the Studites can only have been one of a number of groups

1. Washington, Dumbarton Oaks Coll., cod. 3 (S. Der Nersessian, «A Psalter and New Testament Manuscript at Dumbarton Oaks», DOP 19 [1965], p. 155-83); Paris. gr. 64 (H. Omont, Miniatures des plus anciens manuscrits grecs de la Bibliothèque Nationale du $V T^{e}$ au XIV $V^{e}$ siècle ${ }^{2}, \mathrm{~Pa}-$ ris 1929, p. 46, pls. LXXXIV-LXXXVI); Rome, Biblioteca Apostolica Vaticana, Urb. gr. 2 (C. Stornajolo, Miniature delle omilie di Giacomo Monaco e dell'Evangeliario greco urbinate, Rome 1910, pls. 83-91). For the opportunity to examine the manuscript I wish to thank Dr. Elizabeth Burin, Assistant Curator of Manuscripts and Rare Books, the Walters Art Gallery. Figures 1, 2, 10, 12, 13, 16, 19 are published by the permission of the Walters Art Gallery; fig. 3 by permission of Harvard University; fig. 4 by permission of the Bibliothèque publique et universitaire, Geneva; figs. 5, 6 by permission of the Öffentliche Bibliothek der Universität Basel; figs. 7, 8 by permission of the National Library, Athens; figs. 17, 18, 19 are published through the courtesy of the Michigan-Princeton-Alexandria Expedition to Mount Sinai; and figs. 9, 11, 15 are after the Treasures of Mount Athos.

2. J. Anderson, «The Date and Purpose of the Barberini Psalter", CahArch 31 (1983), p. 42-56.

3. The term «praxapostolos» appears in various lists, among them the diataxis of Michael Attaliates, ed. P. Gautier, «Le Diataxis de Michel Attaliate», REB 39 (1981), p. 95, 11. 1276-77; and the Patmos inventory: C. Astruc, «L'inventaire dressé en Septembre 1200 du trésor et la bibliothèque de Patmos: édition diplomatique», TM 8 (1981), p. 23. to shape the course of medieval Byzantine illumination. An episode in the twelfth-century life of the abstract manner is the subject of this essay. In particular, I am concerned with the place held by a Baltimore manuscript within a known group of works. The manuscript is Walters Art Gallery cod. 533, which contains the Acts of the Apostles, Pauline and Catholic Epistles. It is the type of book a contemporary would have called a praxapostolos ${ }^{3}$. The American collector Henry Walters (1848-1931) acquired the Praxapostolos, along with a number of other manuscripts, from the French bookbinder and agent Léon Gruel (1841-1923) ${ }^{4}$. The Praxapostolos was one of several Walters manuscripts that had been in monasteries of Mt. Athos; S. Lambros catalogued it as Iviron monastery codex $24^{5}$. After the purchase, the manuscript was examined by the philologist $\mathrm{K}$. Clark, who published a description of its contents and, slightly later, a collation of the biblical text ${ }^{6}$.

4. L. Randall, Medieval and Renaissance Manuscripts in the Walters Art Gallery, I, France 875-1420, Baltimore 1989, p. xii.

5. S. Lambros, Catalogue of the Greek Manuscripts on Mount Athos, II, Cambridge 1900, p. 3 (no. 4144); K. Aland, Kurtzgefasste Liste der griechischen Handschriften des Neuen Testaments, Berlin 1963, p. 115 (no. 1022); J. Duplacy, «Manuscrits grecs du Nouveau Testament émigrés de la Grande Laure de l'Athos», Studia Codicologica, ed. K. Treu, Texte und Untersuchungen zur Geschichte der altchristlichen Literatur, CXXIV, Berlin 1977, p. 161.

The other Athos manuscripts that Walters purchased through Gruel are: W 527 (K. Clark, A Descriptive Catalogue of Greek New Testament Manuscripts in America, Chicago 1937, p. 357; from the Dochiariou monastery: Illuminated Greek Manuscripts from American Collections, ed. G. Vikan, Princeton 1973, p. 71), W 530c (Clark, Descriptive Catalogue, p. 360; from Vatopedi 762: K. Weitzmann, «The Psalter Vatopedi 761 and its Place in the Aristocratic Psalter Recension", Journal of the Walters Art Gallery 10 [1947], p. 22); W 530d, e (from Lavra A.44: Illuminated Greek Manuscripts from American Collections, p. 139); W 530f (from Lavra A.76: K. Weitzmann, «A Fourteenth-Century Greek Gospel Book with Wash Drawings», GBA 62 [1963], p. 4-98). See also Duplacy, op.cit., p. 161-62.

6. Clark, Descriptive Catalogue, p. 365-67, pl. LX (fol. 107v); idem, Eight American Praxapostoloi, Chicago 1941, p. 20-22 and passim, pl. III (fol. 107v). He reports no manuscripts closely related by text type. 
A small selection of author portraits appeared in the 1940s, and in 1974 S. Der Nersessian published a thorough arthistorical study of the miniatures ${ }^{7}$. Certain questions nonetheless surround the Walters Praxapostolos. Among them are the manuscript's date, the purpose it was made to serve, the content of the miniatures, and the relationship it bears to an illustrated praxapostolos at Mt. Sinai.

\section{Date of the Praxapostolos}

The Walters Praxapostolos was written and illuminated sometime during the first half of the twelfth century, possibly in the decade approaching 1150 or slightly thereafter. The manuscript contains no documentary evidence, so dating is based on similarities with books that are dated. Its illustration can be specifically related to that found in a large number of manuscripts, some of which are clearly dated and others of which contain evidence that points to some limit. Among the other works that define the movement to which the Praxapostolos belongs are the following, listed by content:

7. K. Weitzmann, «An Early Copto-Arabic Miniature in Leningrad», Ars Islamica 10 (1943), p. 119-34, figs. 2-4. Early Christian and Byzantine Art, Baltimore 1947, p. 142 (no. 720) and figure (fol. 216v). S. Der Nersessian, "The Praxapostolos of the Walters Art Gallery», Gatherings in Honor of Dorothy E. Miner, eds. U. McCracken, L. Randall, R. Randall, Jr., Baltimore 1974, p. 39-50.

8. S. De Ricci and W. Wilson, Census of Medieval and Renaissance Manuscripts in the United States and Canada, I, New York 1935, p. 971. Illuminated Greek Manuscripts from American Collections, p. 128-29; L. Nees, «An Illuminated Byzantine Psalter at Harvard University», DOP 29 (1975), p. 207-24. I. Spatharakis, Corpus of Dated Greek Manuscripts to the Year 1453, Leiden 1981, p. 38, figs. 225-28. A. Cutler, The Aristocratic Psalters in Byzantium, Paris 1984, p. 35-36, figs. 110-15. G. Papazoglou, «Le Michel Cantacuzène du Codex Mavrocordatianus et le possesseur homonyme du psautier de Harvard», REB 46 (1988), p. 163-65.

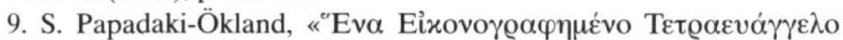

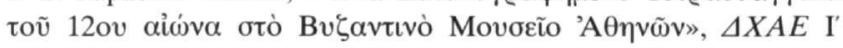
(1980-81), p. 289-306, figs. 77-81; Spatharakis, Dated Illuminated Manuscripts, p. 39, fig. 233 (fols. 40v-41).

10. A. Marava-Chatzinicolaou and Ch. Toufexi-Paschou, Catalogue of the Illuminated Byzantine Manuscripts of the National Library of Greece, I, Athens 1978, p. 224-43, figs. 630-54; Aland, op. cit., p. 103 (no. 777). E. Constantinides, «The Tetraevangelion, Manuscript 93 of the Athens National Library", $\triangle X A E \Theta^{\prime}$ (1977-1979), p. 185-215, pls. 61-83.

11. J.-M. Olivier and M.-A. Monégier du Sorbier, Catalogue des manuscrits grecs de Tchécoslovaquie, Paris 1983, p. 9-13, pls. XVI, XVIII-XX; Aland, op. cit., p. 65 (no. 86). K. Benda and J. Myslivec, "The Illuminations of the Codex Mavrocordatianus», Byzantinoslavica 38 (1977), p. 1-13, figs. 1-8. B. Fonkič, «Zum Kolophon vom Jahre 1183 und der Datierung des Codex Mavrocordatianus», Byzantinosla-
Psalter:

Cambridge, Harvard College Library, MS gr. 3; dated ca. 1104 (fig. 3) ${ }^{8}$.

\section{Gospels:}

Athens, Byzantine Museum, cod. 204; dated $1108^{9}$.

Athens, Ethnike Bibliotheke, cod. 93 (figs, 7, 8) ${ }^{10}$.

Bratislava, Ustrredn á Kniznica Slovenskej Akadémie Vied-Usek starej literatury, 394; Codex Mavrocordatianus, produced sometime before $1183^{11}$.

Geneva, Bibliothèque publique et universitaire, cod. 19 (fig. 4) ${ }^{12}$.

Kalavryta (near), monastery of the Mega Spelaion, cod. $8^{13}$.

Odessa, A. M. Gorky State Scientific Library, cod. $567^{14}$.

\section{Praxapostolos:}

Baltimore, Walters Art Gallery, cod. W 533 (figs. 1, 2, 10, 12, 13, 16, 19).

Paris, Bibliothèque Nationale, suppl. gr. 1262; dated $1101^{15}$.

vica 41 (1980), p. 224-27; Papazoglou, op. cit., p. 161-65. R. Nelson, The Iconography of Preface and Miniature in the Byzantine Gospel Book, New York 1988, p. 22-23, figs. 10-13.

12. H. Omont, «Catalogue des manuscrits grecs des bibliothèques de Suisse», Centralblatt für Bibliothekswesen 3 (1886), p. 46; Aland, op. cit., p. 65 (no. 75). C. Meredith, «The Illustration of Codex Ebnerianus. A Study in Liturgical Illustration of the Comnenian Period», JWarb 29 (1966), p. 420-21. Nelson, op. cit., fig. 9; J. Anderson, «The Past Reanimated in Byzantine Illumination, Byzantine East, Latin West", Art-Historical Studies in Honor of Kurt Weitzmann, ed. D. Mouriki, Princeton 1995, p. 320, fig. 2.

13. N. Bees, Verzeichnis der griechischen Handschriften des Peloponnesischen Klosters Mega Spilaeon, I, Leipzig 1915, p. 7-9; Aland, op. cit., p. 177 (no. 2229). G. Tsimas and P. Papahadzidakis, Miniatures of Mega Spilaeon, Athens n.d., pls. 39-59; Nees, op. cit., figs. 10-12; Papadaki-Ökland, op. cit., pl. 82. Text and miniatures do not seem to have been part of the same commission, although the text looks like work that could not be dated earlier than the second half of the eleventh century.

14. K. Treu, «Die griechischen Handschriften des Neuen Testaments in der UdSSR», Texte und Untersuchungen zur Geschichte der altchristlichen Literatur, XCI, Berlin 196(5. p. 347-48; Aland, op. cit., p. 178 (no. 2550). V. Putzko, «Miniatyuri Četveroevangeliya ie Monastiyra Protat na Afoie (Moskva, GIN, Syn. Gr. 519)», $\triangle X A E \mathrm{I}^{\prime}$ (1980-81), p. 65-70, figs. $9 \alpha, 10 \alpha, \beta$.

15. C. Astruc and M.-L. Concasty, Catalogue des Manuscrits grecs, III, Le supplément grec, 3, Nos. 901-13371, Paris 1960, p. 500-501; Aland, op. cit., p. 159 (no. 1885). N. Wilson, «Scholarly Hands of the Middle Byzantine Period", La paléographie grecque et byzantine, Paris 1977, p. 229; Nees, op. cit., p. 216-18, figs. 7-9.

When the Suppl. gr. 1262 entered the Bibliothèque Nationale from 

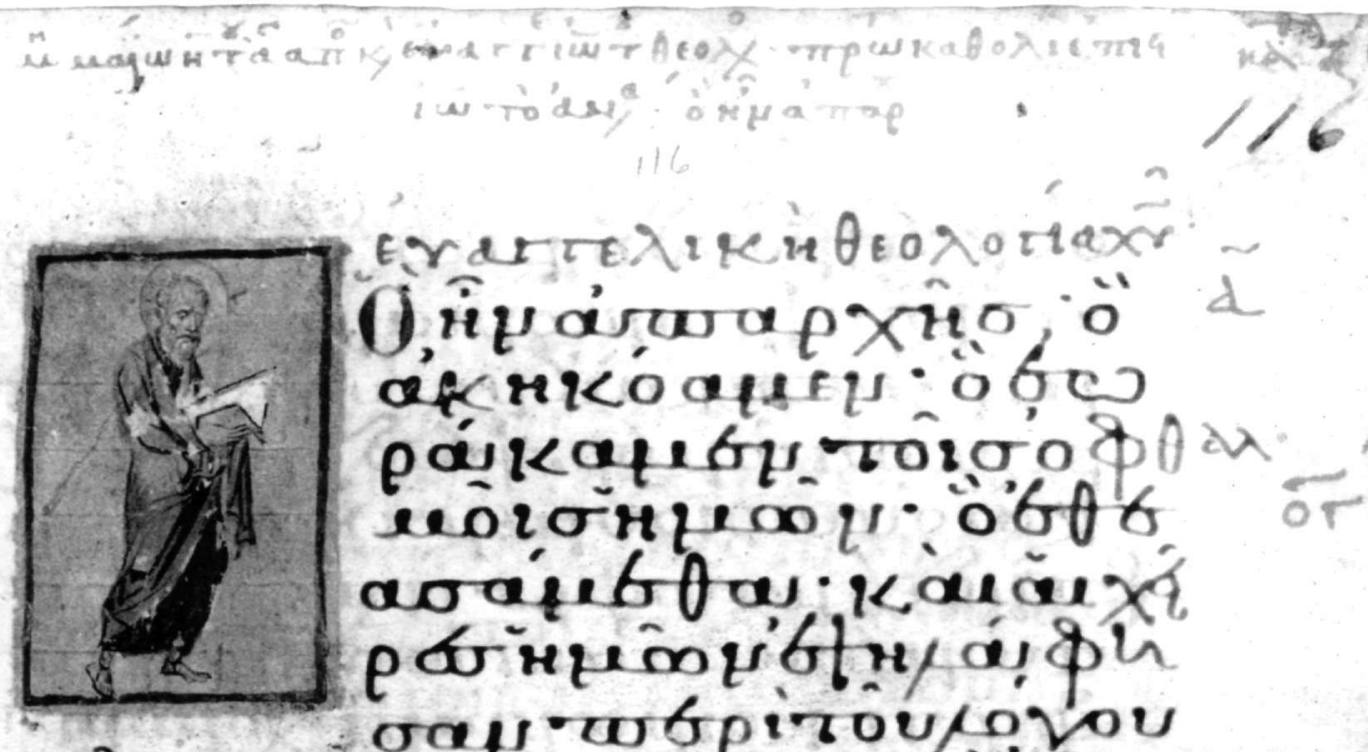

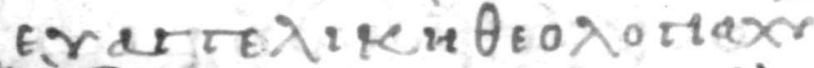

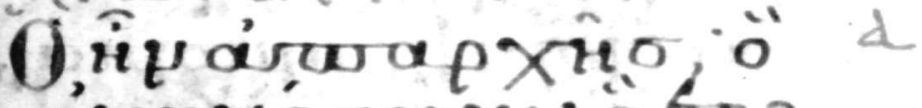

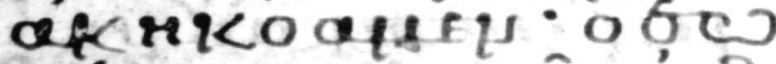

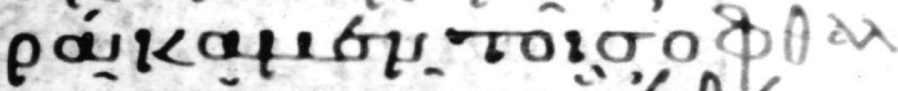

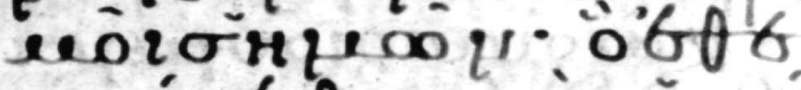

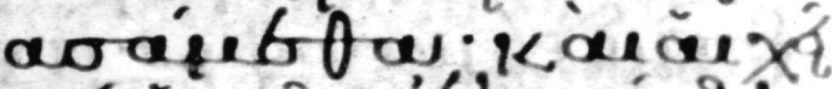

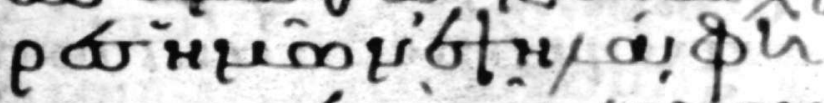

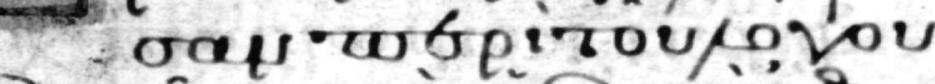

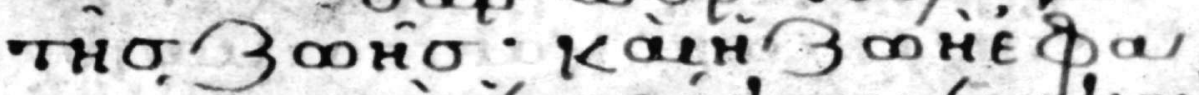
ug कि

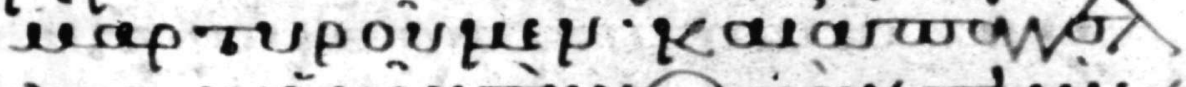

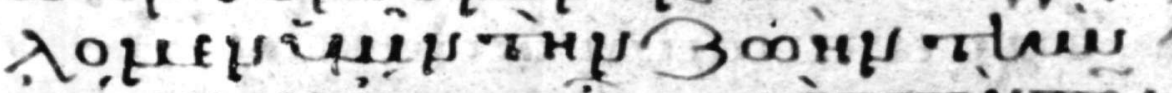

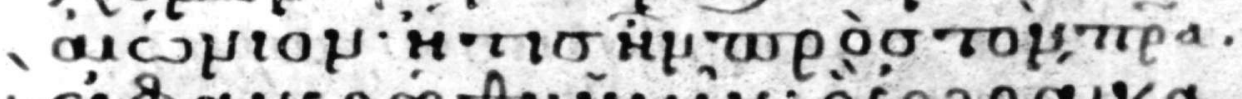
Sé क्रिE

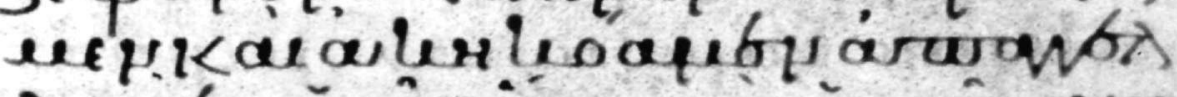

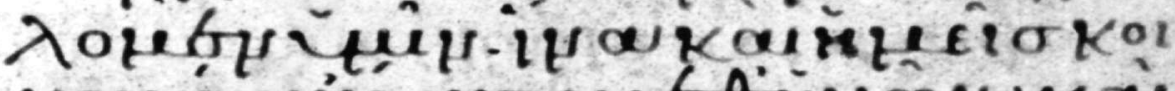

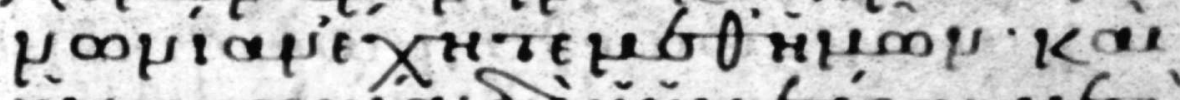

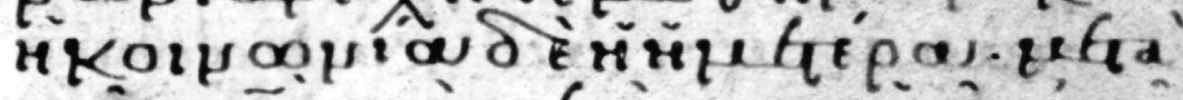

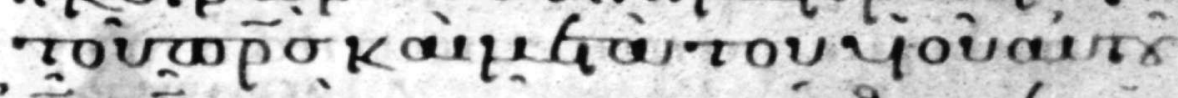

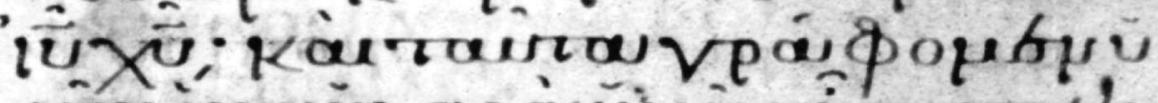

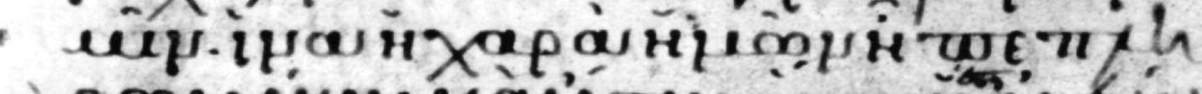

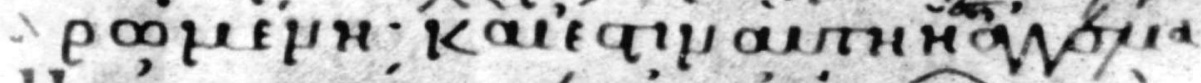

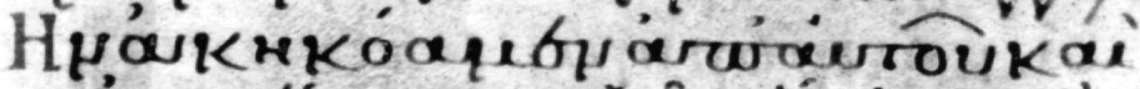

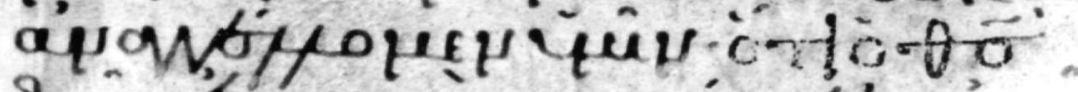

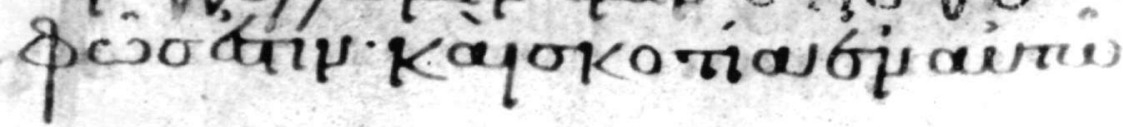




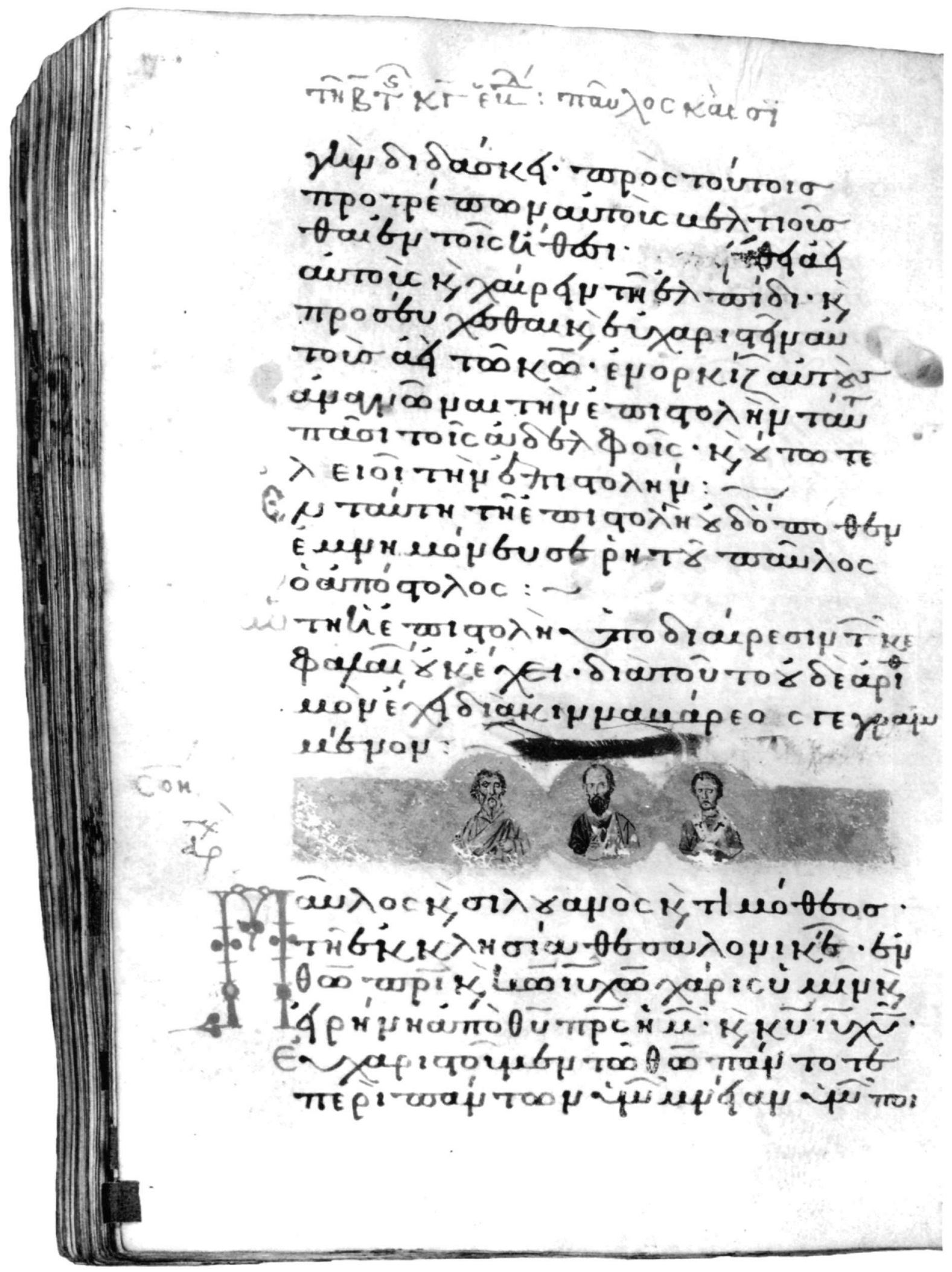

Fig. 2. Baltimore, Walters Art Gallery, cod. 533, fol. 255v: Timothy, Paul, Silas. 
New Testament:

Basel, Öffentliche Bibliothek der Universität Basel, cod. A.N.IV.2 (figs. 5,6$)^{16}$.

\section{Biblical, Homiletic, Canonical collection:}

Mt. Athos, Pantokrator Monastery Library, cod. 234; produced sometime after 1102 or 1117 (figs. 9, 11) ${ }^{17}$.

In addition to these works, there are a handful of others that will not be discussed here but that deserve mention; they are: Athens, Ethnike Bibliotheke, cod. $15^{18}$; Mt. Sinai, Monastery of St. Catherine, cod. gr. $418^{19}$; Paris, Bibliothèque Nationale, cod. gr. 55020; Rome, Biblioteca Apostolica Vaticana, gr. $1927^{21}$. The problem that arises is whether the group represents a broad movement in early twelfth-century Byzantine art or the product of a longstanding group of illuminators active well into the century's first quarter. Perhaps circumstances resulted in the eventual confusion of the two: what began as the work of a small group came to be emulated by others.

one of the monasteries of the Meteora (H. Omont, Missions archéologiques françaises en Orient aux XVII et XVIII siècle, II, Paris 1902, p. 856 n. 6), it had leaves missing, and some cuttings in St. Petersburg, State Public Library, gr. 321, are said to have a Meteora provenance (known to K. and S. Lake, Dated Greek Minuscule Manuscripts to the Year 1200, VI, Boston 1936, p. 15, pl. 443). The Meteora manuscripts were catalogued by the Russian Archbishop Porphyrios Uspenskij (A. Berendts, «Die Bibliotheken der Meteorischen und Ossa-Olympischen Klöster», Texte und Untersuchungen zur Geschichte der altchristlichen Literatur, $\mathrm{XI} / 3$ [1904], p. 67-70), who is notorious for having taken cuttings of dated or otherwise exceptional manuscripts. E. Granstrem, «Katalog grečeskich rukopisej Leningradskich Chranilisč IV, Rukopisi XII veka», VizVrem 23 (1963), p. 169 (no. 310) identified the Paris Praxapostolos as the source of the cuttings (an identification repeated by Spatharakis, Dated Illuminated Manuscripts, p. 37-38). The title page to Hebrews, originally between fols. 339 and 340, has been acquired by the Metropolitan Museum of Art, New York, acc. no. 1991.232.15.

16. H. Omont, "Catalogue des manuscrits grecs des bibliothèques de Suisse: Bâle, Berne, Einsiedeln, Genève, Saint-Gall», Centralblatt für Bibliothekswesen 8 (1891), p. 7; K. Escher, Die Miniaturen in den Basler Bibliotheken, Museen und Archiven, Basel 1917, p. 20-21, pl. I, 1; Aland, op. cit., p. 61 (no. 1 eap). K. Lake, «Codex 1 of the Gospels and its Allies», Texts and Studies, VII, Cambridge 1902, p. ix-xiv, passim and frontispiece; Nelson, op. cit., fig. 15.

17. S. Lambros, Catalogue of the Greek Manuscripts on Mount Athos, I, Cambridge 1895, p. 112-113; Aland, op. cit., p. 135 (no. 1404). G. Galavaris, The Illustrations of the Prefaces in Byzantine Gospels, Vienna 1979, p. 63, figs. 45-48. S. Pelekanides, P. Christou, Ch. Mavropoulou-

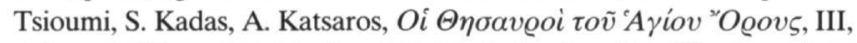
Athens 1979, p. 283-87, figs. 242-57; I. Spatharakis, The Portrait in Byzantine Illuminated Manuscripts, Leiden 1976, p. 230-32, fig. 174.

18. Psalter: Cutler, op. cit., p. 17, figs. 13-18; P. Buberl, Die Miniaturenhandschriften der Nationalbibliothek in Athen, Vienna 1917, p. 16, relates
The formulation of the manuscript group began in 1975, when L. Nees published the psalter at Harvard and related it to the praxapostolos in the Bibliothèque Nationale and the Gospel book in the Mega Spelaion monastery (fig. 3$)^{22}$. Five years later, R. Nelson called attention to the similarity between the Geneva Gospels and the Codex Mavrocordatianus; he also reproduced, without comment, the one surviving miniature in the Basel New Testament, a miniature similar in style and content to ones in the Geneva Gospels and Codex Mavrocordatianus (figs. 4-6) (23 $^{23}$ Around the same time, S. Papadaki-Ökland published the Gospel book in the Byzantine Museum, which she related to the Codex Mavrocordatianus, the Mega Spelaion Gospels and Harvard Psalter ${ }^{24}$. Yet another Gospel book of similar type and style was discovered at Odessa and published by V. Putzko in $1981^{25}$. The illustrations in the Basel New Testament and five copies of the Gospels (excepting Athens cod. 93) form a relatively coherent group in which the Harvard Psalter is at home, despite the different demands of its text.

to the Gospel book, cod. 93 (a relationship later endorsed by O. Demus and E. Constantinides in studies cited in notes 26 and 10).

19. Heavenly Ladder: V. Gardthausen, Catalogus codicum graecorum sinaiticorum, Oxford 1886, p. 100-101. J. Martin, The Illustration of the Heavenly Ladder of John Climacus, Princeton 1954, p. 87-104, 187-89, figs. 174-216; K. Weitzmann and G. Galavaris, The Monastery of Saint Catherine at Mount Sinai, The Illuminated Greek Manuscripts, I, From the Ninth to the Twelfth Century, Princeton 1990, p. 153-62, figs. 587-631.

20. Select sermons of Gregory of Nazianzen: H. Omont, Inventaire sommaire des manuscrits grecs de la Bibliothèque nationale, I, Paris 1886 , p. 83-84; H. Bordier, Description des peintures et autres ornements contenus dans les manuscrits grecs de la Bibliothèque nationale, Paris 1883, p. 198-203. Omont, Miniatures des plus anciens manuscrits grecs, pls. CVI-CXV; G. Galavaris, The Illustrations of the Liturgical Homilies of Gregory Nazianzenus, Princeton 1969, p. 242-45 and passim, figs. 398-424.

21. Psalter: P. Canart, Codices vaticani graeci. Codices 1745-1962, I, Vatican City 1970, p. 693-95. P. Canart and V. Peri, «Sussidi bibliografici per i manoscritti greci della Biblioteca vaticana", Studi e testi, CCLXI, Vatican City 1970, p. 659-60; M. Buoncore, «Bibliografia dei fondi manoscritti della Biblioteca vaticana (1968-1980)", II, Studi e testi, CCCXIX, Vatican City 1986, p. 942-43; M. Ceresa, «Bibliografia dei fondi manoscritti della Biblioteca vaticana (1981-1985)", Studi e testi, CCCXLII, Vatican City 1991, p. 405-6. E. De Wald, The Illustrations in the Manuscripts of the Septuagint, III, Psalms and Odes, 1, Vaticanus Graecus 1927, Princeton 1941.

22. Nees, op. cit., (note 8), p. 210, 216-17, noting frames as a shop trait and commenting on ornament. I wish to thank Prof. Nees for lending the photograph for fig. 3 .

23. Nelson, op. cit. (note 11), p. 323.

24. Papadaki-Ökland, op. cit. (note 9), p. 293, 300-303.

25. Putzko, op. cit. (note 14). 


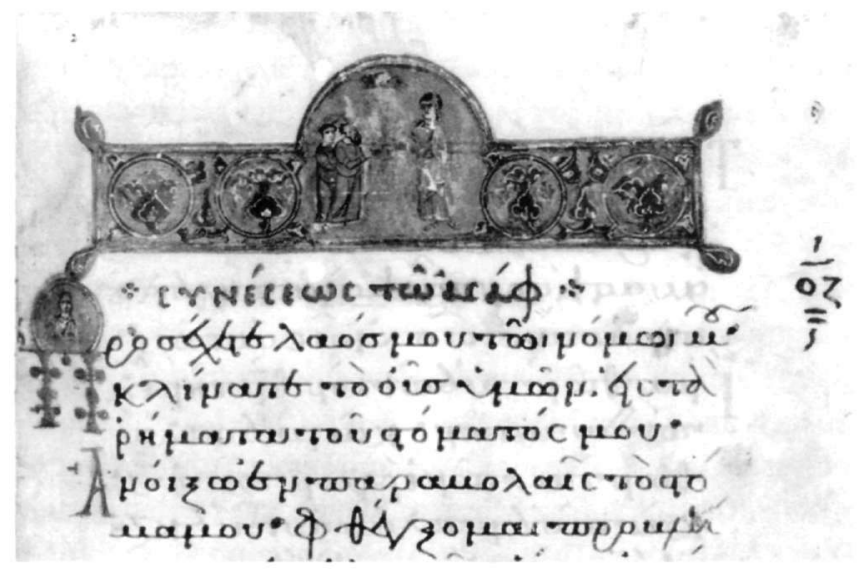

Fig. 3. Cambridge, Harvard College Library, cod. 3, fol. 113: Moses teaching.

The style of illustration, the pictorial content, and the loosely - organized but extensive decoration serve to tie the books together as contemporary products of Constantinople, and perhaps as the effort of a group of craftsmen brought in some way into frequent or regular contact. The term Nees used in his initial discussion of the manuscripts, workshop, conveniently encompasses the two facts that became increasingly plain as more books were added to the original cluster of three. One is the combined strength of various parallels that would be less than compelling if taken individually. The other is the certainty that a number of scribes and illuminators were responsible for the entire production. For example, the illuminator of the Basel Gospels did not have a hand in the Codex Mavrocordatianus, but the illuminator of the Mavrocordatianus most likely painted the miniatures in the Harvard Psalter. As corroborating evidence for filiation, the scripts prove to be more difficult to evaluate.They vary in ways shaped not only by differences in individuals' styles, but also by conventions associated with the particular texts and their intended uses. The delicate, clipped writing of the Basel New Testament, for example, is quite unlike the rolling script of the Harvard Psalter (figs. 3, 6). The lilting cursive of the Paris Praxapostolos presents a third approach, a consciously calligraphic one that calls to mind the Mavrocordatianus in terms of its deliberate artfulness, though not its style. The handwriting of the Mega Spelaion Gospels has nothing to do with that of any other of the manuscripts; its divergence raises the possibility that one or more of the illuminators might on occasion produce illustrations for finished books. The manuscripts thus present considerable variety within a recognizably homogenous field. The clustering of the three dated works acts to anchor the chronology: we can be certain that the style enjoyed popularity at the opening of the twelfth century.

The group became more varied once the Athens Gospels, cod. 93 , had been added (figs. 7, 8). The illustration of the manuscript departs from the program used for the other Gospel books and the Gospel portion of the Basel New Testament. The authors appear alone without feast scenes, and a selection of narrative illustrations was scattered at uneven intervals throughout the Gospel text. Certain qualities of format and execution nevertheless relate this illustrated copy of the Gospels to the other manuscripts in the series. The overall design of the historiated headpiece on fol. $143 \mathrm{v}$ recalls that of a headpiece in the Harvard Psalter (figs. 3, 7); furthermore, both were filled with ornament that consists of stunted, poorly articulated flowers drawn with highlights that fail to create any illusion of curved petals. An equivalently loose approach, one that permits a vast amount of gold to show through, typifies the Geneva Gospels and Basel New Testament (figs. 4-6). In 1979 E. Constantinides published a detailed examination of the narrative miniatures in the Athens Gospels. She showed that the book had been written by two scribes and illuminated by more than one artist. The collaborative nature conforms to the impression created by the variety of miniature and script styles in the manuscripts that constitute the core of the group. Constantinides went on to argue a late twelfth-century date based on parallels from monumental painting. She was not the first to use such evidence for an attribution in the second half of the century. In describing the creative world of the Monreale mosaics (1180s), O. Demus had cited the miniatures as work of about $1170^{26}$. Constantinides expanded and modified the argument. The most important of the manuscript parallels she considered to be a psalter in the Athens National Library (cod. 15); in addition, she cited the Walters Praxapostolos, another psalter in Athens (Ethnike Bibliotheke cod. 7), the Vatican Psalter, cod. gr. 1927, and the Kokkinobaphos manuscripts ${ }^{27}$. All are either undated or too early to sup- 


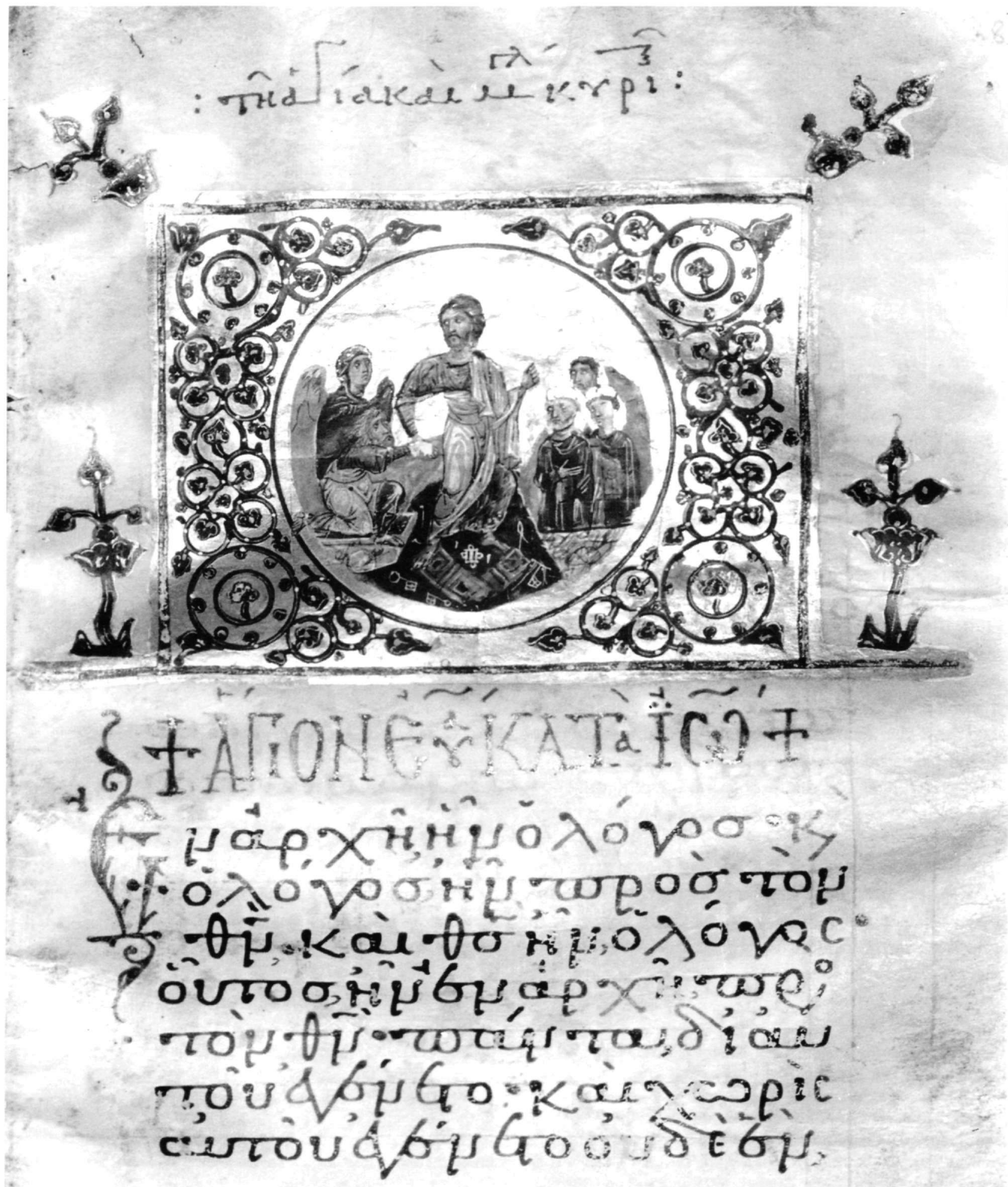

Fig. 4. Geneva, Bibliothèque publique et universitaire, cod. 19, fol. 382v: Anastasis. 
port the late attribution, so she turned to wall painting ${ }^{28}$. The argument Constantinides advanced relates the tall, thin proportions of the figures and their often fluttering drapery to the style of Byzantine painting that is found at the hermitage of St. Neophytos at Paphos (1180s) and the Panagia tou Arakos of Lagoudera (1192), among other examples that date in the last two decades of the century ${ }^{29}$. As our knowledge of Byzantine painting toward the end of the century deepens, the late attribution of the Athens Gospels seems less defensible ${ }^{30}$. The style of monumental painting strongly marked by tall, thin figures, energetic compositions and exuberant drapery patterns has its earliest surviving example in a dated work produced well before the end of the century. The frescoes in the church of St. Panteleimon at Nerezi offer parallels in a monument containing a dedication inscribed in the year $1164^{31}$. Traits like the tall, slender proportions can be found in the early twelfth-century Paris Praxapostolos ${ }^{32}$. Drapery patterns occasionally represented in the Geneva Gospels and others at the core of the group can be quite energetic; and if they sometimes seem insufficiently so, other works dated in the century's first decade attest to a keen interest in movement ${ }^{33}$. Constantinides' redating of the manuscript from the 1170 s to end of century may be difficult to defend if an alternative can be formulated. But what needs to be emphasized is that as the list of works grows it becomes more varied in terms of scripts, miniature styles and, perhaps most significantly, contents. The elements of continuity must depend on some pattern of artistic interaction current for decades. The first problem is documenting how late the manner continued to be practiced in a recognizable form.

The discussion surrounding the Athens Gospels may be reduced to the question, How far into the 1100 s did the style so well attested at the century's start continue in recognizable form? Evidence suggests that it lasted into

28. The exception is the Psalter, Cod. Athen. 7, which seems to fall outside the group as a later twelfth-century manuscript; Demus, op. cit., p. 435 , relates it to Monreale.

29. Constantinides, op. cit., p. 212-15. In some regards the frescoes at Kurbinovo also might have offered as evidence for her argument; L. Hadermann-Misguich, Kurbinovo. Les fresques de Saint-Georges et la peinture byzantine du XII ${ }^{e}$ siècle, Brussels 1975, p. 25-42 and 321-562, examines in great detail aspects of this phase of Byzantine painting. 30. In addition to Hadermann-Misguich, op. cit., see: K. Weitzmann, «Eine spätkomnenische Verkündigungsikone des Sinai und die zweite Welle des 12. Jahrhunderts", Festschrift für Herbert von Einem zum 16. Februar 1965, eds. G. von der Osten and G. Kauffmann, Berlin 1965,

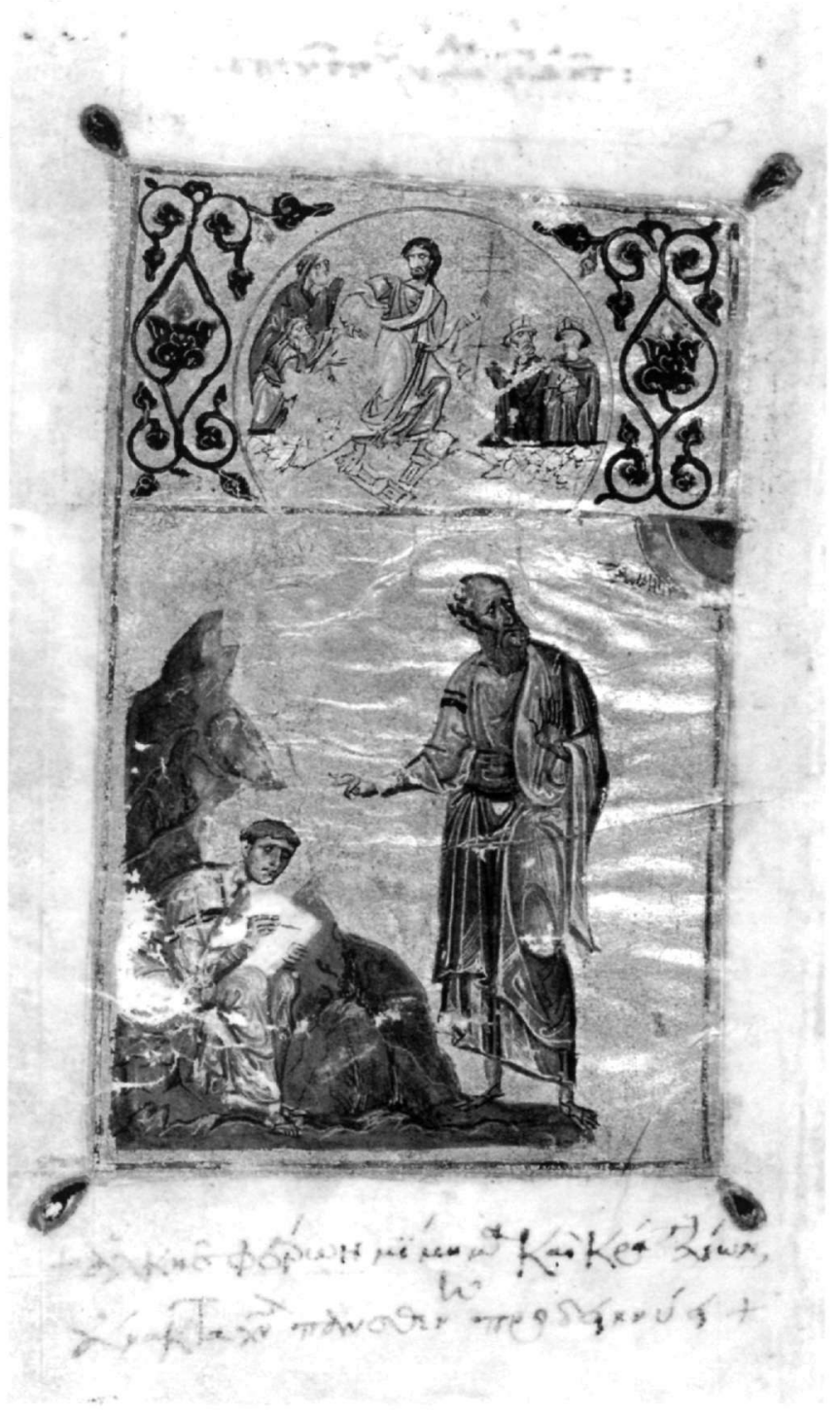

Fig. 5. Basel, Öffentliche Bibliothek der Universität Basel. cod. A.N.IV.2, fol. 265v: Anastasis, John and Prochoros.

p. 299-312; D. Mouriki, «Stylistic Trends in Monumental Painting of Greece during the Eleventh and Twelfth Centuries", DOP 34-35 (1980-81), p. 100-24; H. Buchthal, «Studies in Byzantine Illumination in the Thirteenth Century», Jahrbuch der Berliner Museen 25 (1983), p. 27-102; M. Panayotidi, «La peinture monumentale en Grèce de la fin de l'Iconoclasme jusqu'à l'avènement des Comnènes (843-1081)", CahArch 34 (1986), p. 75-108.

31. G. Zacos and A. Veglery, Byzantine Lead Seals, 1/3, Basel 1972, p. 1527 (it. 2726). P. Miljković-Pepek, Nerezi, Belgrade 1966.

32. See the headpiece on fol. 35: Nees, op. cit. (note 8), p. fig. 7.

33. See Mt. Athos, Gregoriou monastery, cod. 157, dated ca. 1108 by paschal tables: Cutler, op. cit. (note 8), p. 21, figs. 33-36; S. Pelekani- 


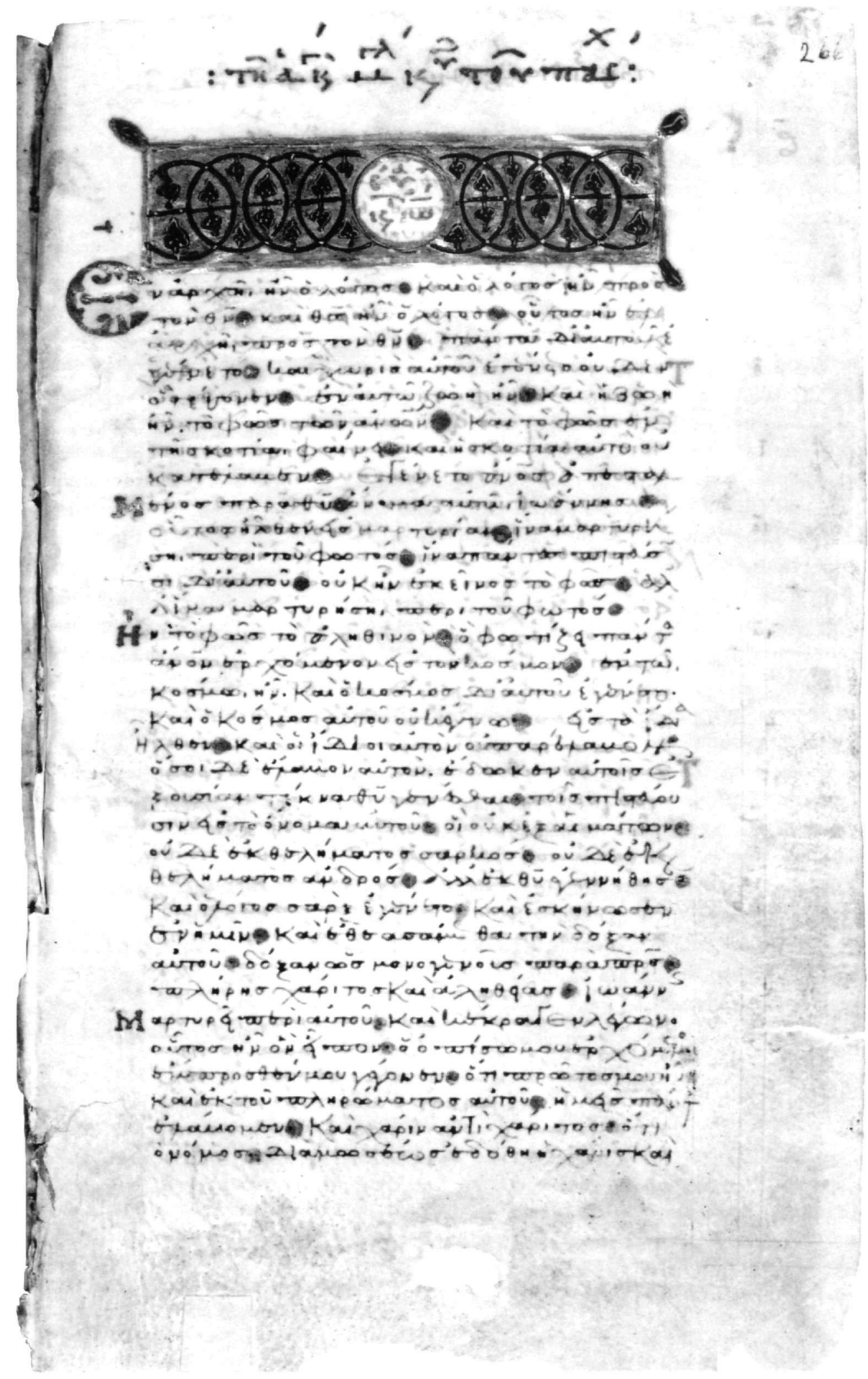

Fig. 6. Basel, Öffentliche Bibliothek der Universität Basel, cod. A.N.IV.2, fol. 26: John's Gospel. 
the middle of the century. The principal evidence comes from a work closely related to the Walters Praxapostolos, Pantokrator cod. 234, a collection of sacred, homiletic, legal and dogmatic writings (figs. 9, 11). Although the Pantokrator Miscellany (as I will refer to the manuscript) is undated, it does contain several twelfth-century texts or editions. One is a novel Alexios I Komnenos (fol. $424 \mathrm{r}+\mathrm{v}$ ) isued in either 1102 or $1117^{34}$. Another is the edition of conciliar material (fols. 288-98v) attributed to the twelfthcentury canonist Alexios Aristenos ${ }^{35}$. Although the date of the redaction has not been established, it cannot have been carried out at the beginning of the century. Aristenos was active during the reign of John II Komnenos, and alive during the early part of Manuel's reign ${ }^{36}$. If made during Aristenos' lifetime, the manuscript could possibly be as early as mid-twelfth century. The clipped, square handwriting of the Miscellany strongly resembles the hand of the Basel New Testament (figs. 6, 9, 11), and the manner and style of illumination also recall those of the New Testament. A closer study of the contents of the Pantokrator Miscellany may yield more substantial evidence for how late in the century the style persisted. What is immediately relevant is that the manuscript was not produced around 1100 , but closer to 1150 .

In the presentation of its contents as well as the styles of handwriting and miniature painting, the Walters Praxapostolos parallels many works of the group, some closely. Like the Geneva Gospels, Basel New Testament and Pantokrator Miscellany, the Praxapostolos is handsomely yet unobtrusively illustrated; that is, the makers sought to create books that retained an ostensibly utilitarian appearance despite their illustration. The impression of practicality was created by the simple miniature frames, which, in the case of the Praxapostolos, are merely lines; the divisions between books was made by lines and strips rather than the wide, faux-enamel bars typical of osten-

des, P. Christou, Ch. Tsioumi, S. Kadas, The Treasures of Mount Athos, I, Athens 1973, p. 465-69. Compare the figure of the Woman of Samaria, fol. 149 of Athens cod. 93, with that of St. Anne in the Presentation scene in the narthex of the church at Daphni (E. Diez and O. Demus, Byzantine Mosaics in Greece. Hosios Lucas and Daphni, Cambridge, MA 1931, fig. 110); figure proportions and drapery articulation denote the same sensibility.

34. F. Dölger, Corpus der griechischen Urkunden des Mittelalters und der neueren Zeit, A, Regesten, I, Munich 1924, p. 57 (no. 1283).

35. Lambros, op. cit. (note 5), p. 113, was apparently struck by the collection and sent a list of its contents to Zachariae von Lingenthal, tatiously expensive manuscripts. Initials appear only at the openings of the individual books of the Bible and are then simple designs executed in carmine and often at a scale not much greater than that of the other letters (figs. 2, 12, 13, $16,19)$. Finally, virtually no space was left between the sections of the manuscript. A typical chapter division in the Praxapostolos can be contrasted with a minor section break in the Dionysiou lectionary, cod. 587, to illustrate the difference between handsome utility and the Byzantine grand manner (figs. 10, 15). A consequence of the decorative austerity is the absence of some evidence that would be useful in dating the manuscript. Handwriting and miniatures are the only indicators of date and filiation, and of them the miniatures are more symptomatic.

The portraits in the Praxapostolos suggest a common tradition shared by illuminators of other manuscripts in the group. The portrait of James, dressed in episcopal regalia and gesturing toward his book, conforms to the type used in creating the illustration in the Pantokrator Miscellany (figs. 9, 10). Stance, proportions, the costume and its articulation all resemble one another. James' portrait is drawn more simply in the Pantokrator manuscript, although the basic structures are about the same, and both feature the pronounced frown that appears elsewhere in the manuscripts. Luke and the members of his assembled audience have been caught in a heated debate (fig. 11); their expressions and the mood of the entire miniature seems tense and charged with a barely bottled-up energy. The compositional structure is that of the scene of Paul addressing the Galatians in the Praxapostolos (fig. 12). One can see the simple reorganization of posture that served to convert the one with standing teacher into the other with seated teacher; the tendency to show the speaker as much larger than the members of his audience marks another of the teaching scenes in the Praxapostolos ${ }^{37}$. Such traits suggest routines that might be found in other elements of execution. In both manuscripts

whose written response Lambros printed. The scribe did not copy a title attributing the redaction to Aristenos, but the Councils generally follow the edition printed by Migne, $P G 113$, col. 63A-105C, with other material associated with Aristenos: G. Rhalles and M. Potles, $\Sigma v v$ -

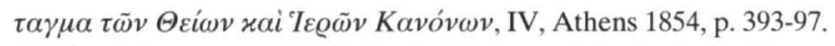
36. On Aristenos see: H.-G. Beck, Kirche und theologische Literatur im byzantinischen Reich, Munich 1959, p. 657; J. Darrouzès, Georges et Démétrios Tornikès. Lettres et discours, Paris 1970, p. 53-57.

37. Fol. 219, Paul addresses the Hebrews (Der Nersessian, Praxapostolos, fig. 13). 


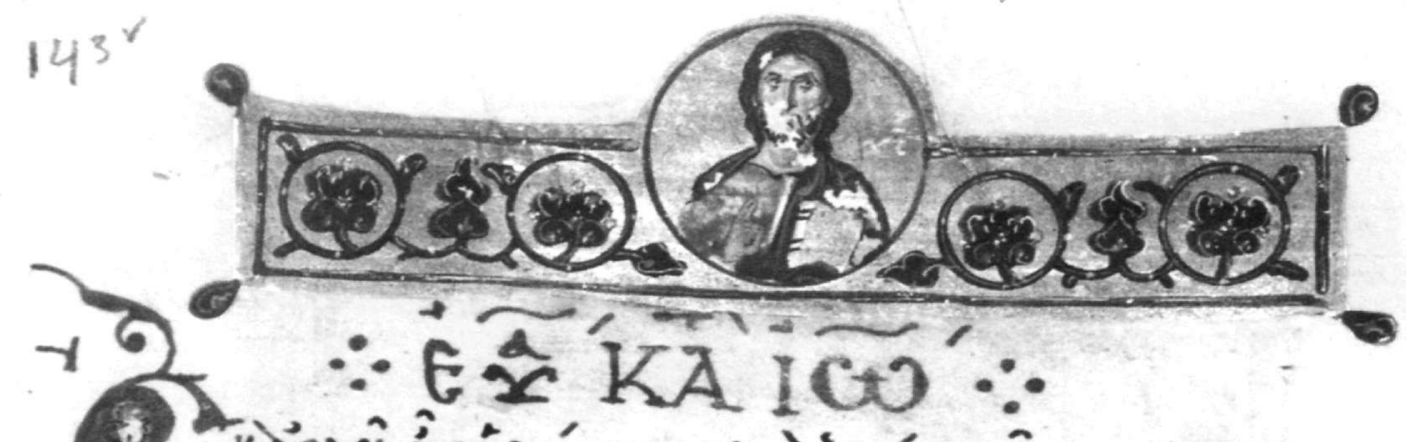

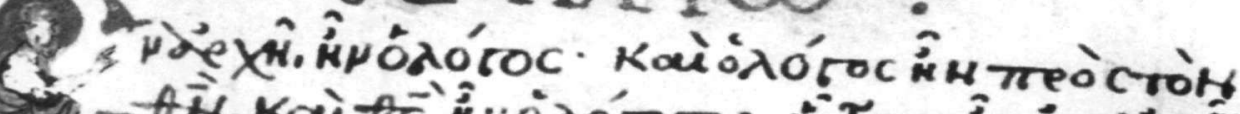

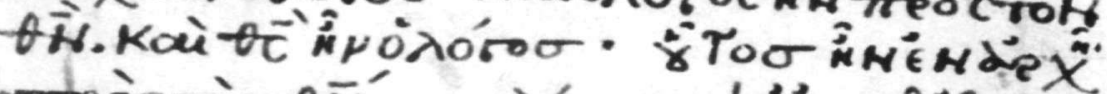

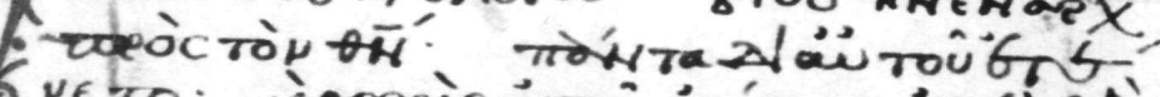

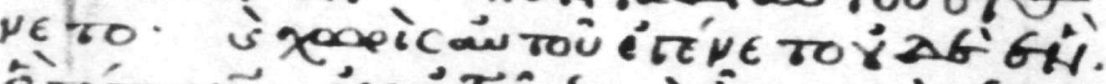

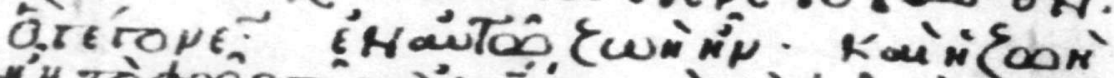

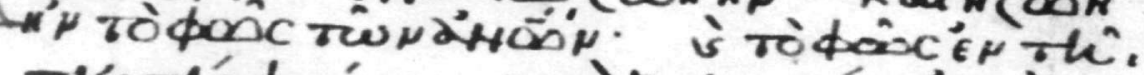

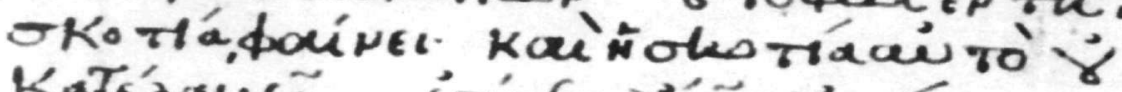

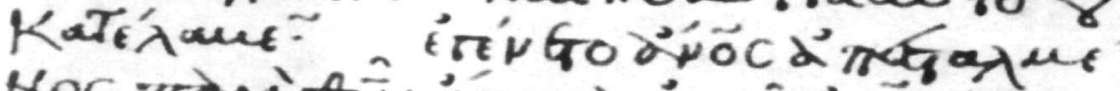

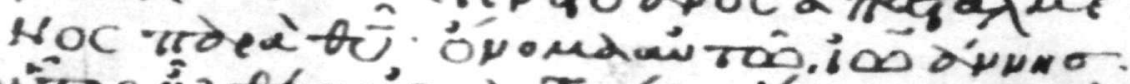

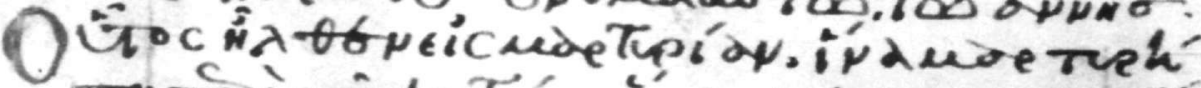

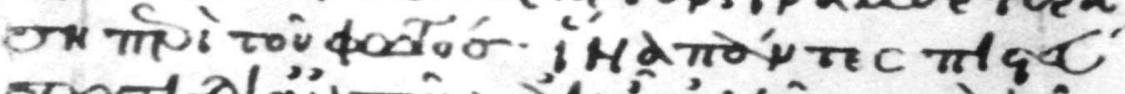

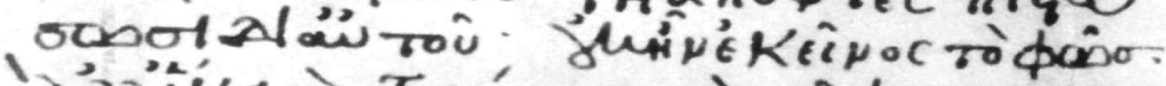

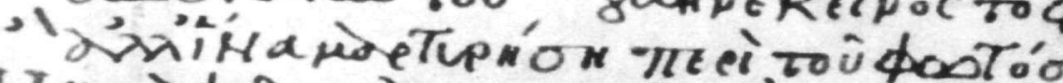

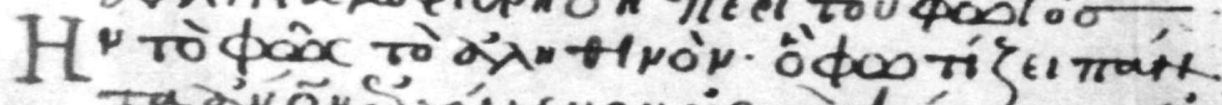

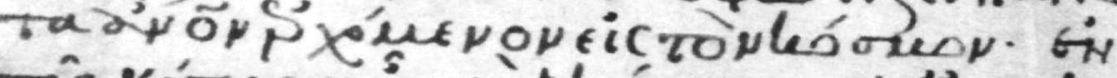

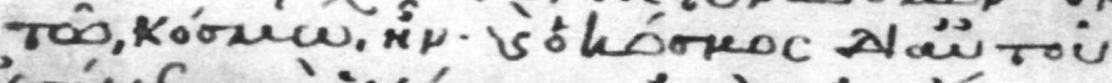

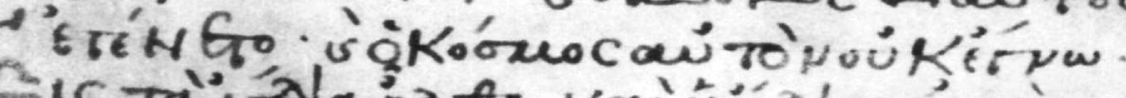

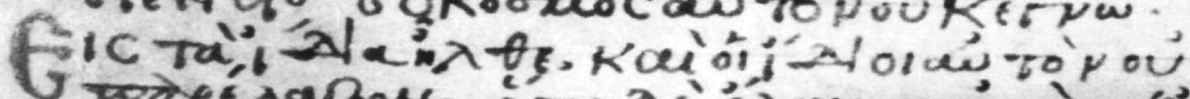

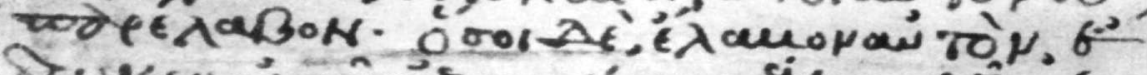

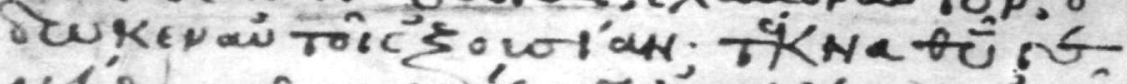

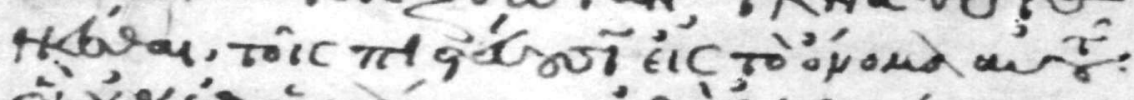

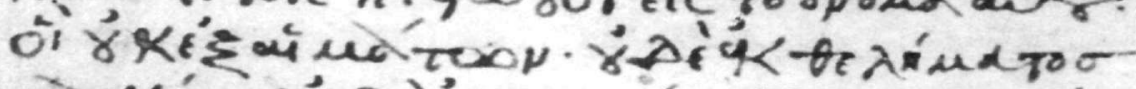

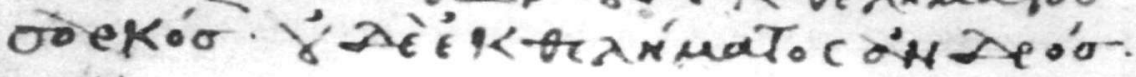

286 


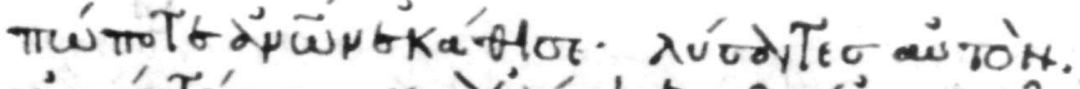

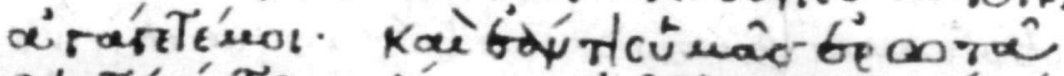

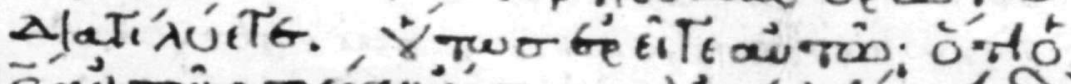

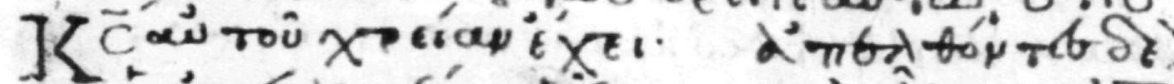

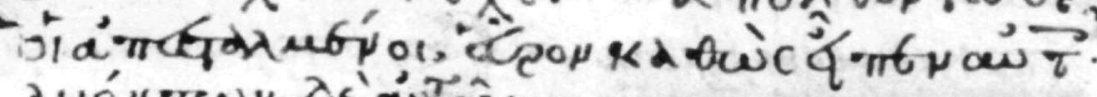

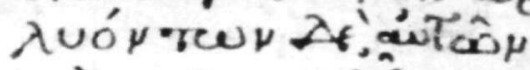

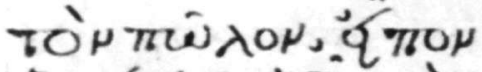

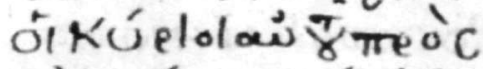

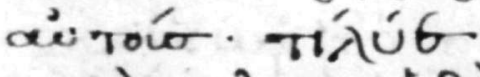

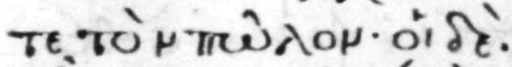

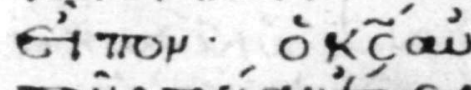

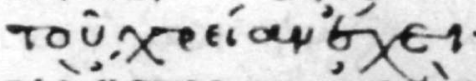

Todi'n raronowtón

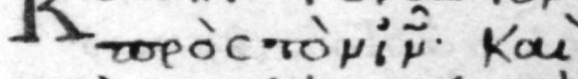
Erol ee ítart \& $G^{2}$ awtón tritud'

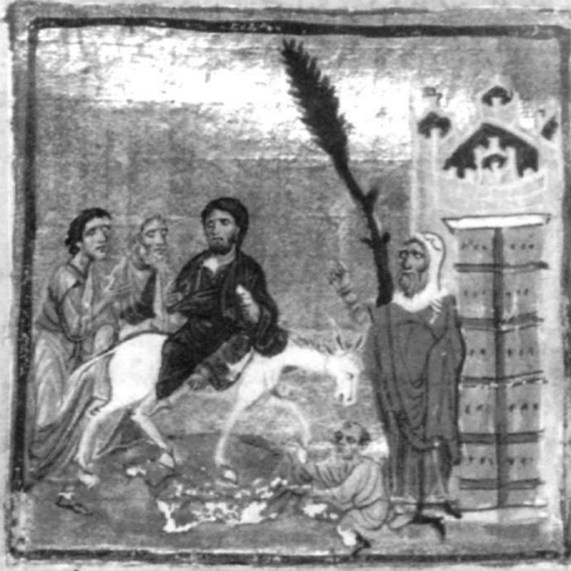

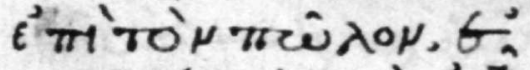

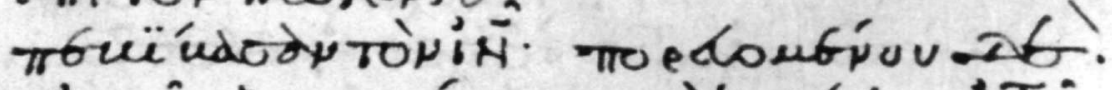

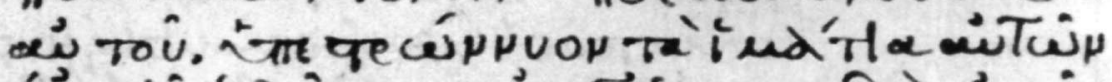

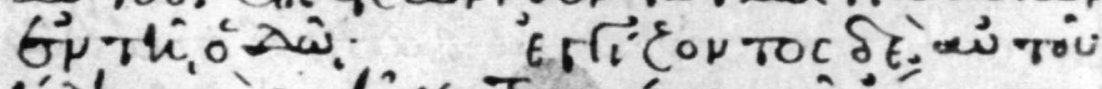

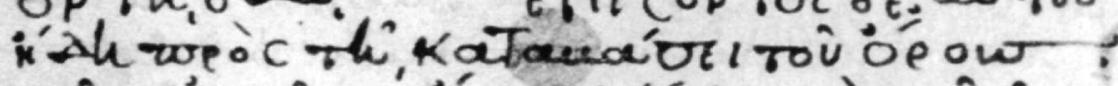

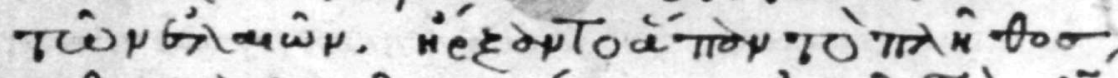

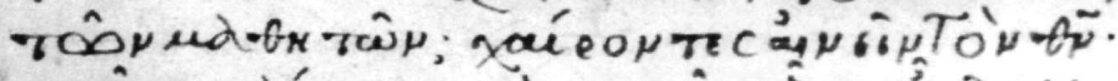

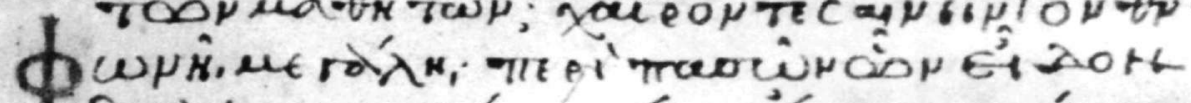

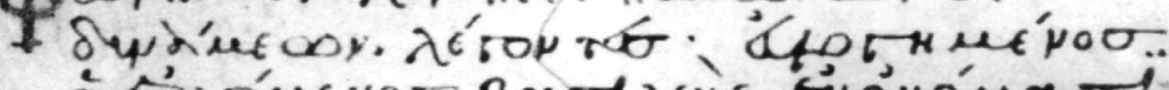

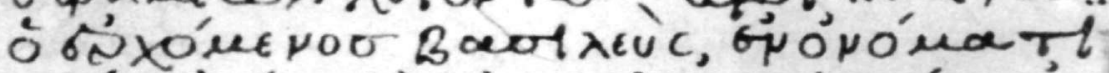

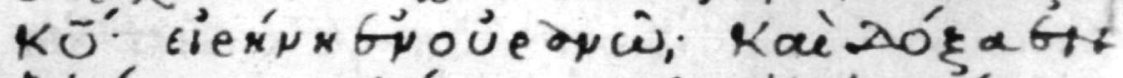

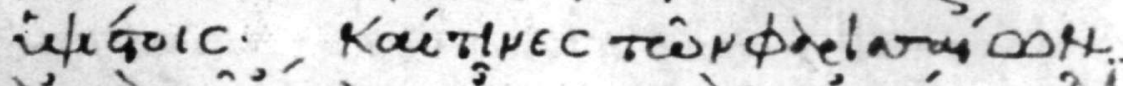

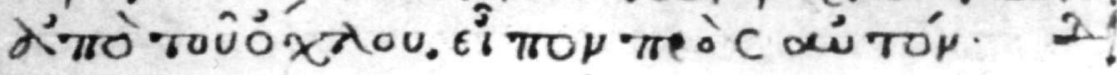

260 
the figures' overgarments break and fold in relatively large planes. The figures listening to Luke in the Miscellany, Paul on fol. 165, or his audience in the miniature on fol. 216v (figs. 11-13) conform to a basic design that was energized with highlight and shadow lines. The articulation of the figures in the Miscellany achieves an almost hectic level that even the most charged portraits in the Praxapostolos fail to achieve. The one full-page illumination of the Basel New Testament represents a direct link to the group fixed around the first decade. The expressions of both author and scribe (fig. 5) appear decidedly anxious. In the smaller-scaled Anastasis of the Basel miniature the draftsmanship and designs for portraits and clothing match those of the Walters Praxapostolos and are related to examples in the Miscellany. The outlines of faces are more complicated than ones found in the Geneva Gospels or Harvard Psalter, in which heads tend to be ovals (figs. 3, 4). The evidence suggests that the Walters Praxapostolos belongs among the works grouped above and that it may be one of the few produced toward the middle of the twelfth century.

The handwriting of the Praxapostolos supports a date around the middle of the century. With a minor exception discussed at the end of this section, the scribe wrote the text in one of two ways. For the marginalia, titles and non-biblical writings, he used half-uncial, the square hand with emphasis on the upright strokes visible in the first five lines of the reproduction of fol. 216v (fig. 12). For the biblical text the scribe wrote in a manner that might be called «liturgical minuscule». He based his choice on the manuscript's intended purpose, which was to serve as a source of readings needed in the liturgy. For the reader, the bold writing made using the book easier, since it is not a large format manuscript. By the twelfth century readings from the praxapostolos were confined to services in which the eucharist was celebrated, when the passage from Acts or the Epistles preceded the one from the Gospels ${ }^{38}$. The restriction may have influenced the scribe's decision to give the writing an especially formal appearance $^{39}$. The basic elements of the liturgical minuscule can be easily described. The scribe wrote using a broad pen, which often leads to strokes of varying thickness; for the liturgical minuscule the scribe strictly limited the degree of

38. The passages are listed by C. Gregory, Textkritik des Neuen Testaments, I, Leipzig 1900, p. 343-68; their specifically Constantinopolitan use may be tracked through J. Mateos, «Le Typicon de la Grande Eglise», III, OCA CLXV-CCLXVI, Rome 1962-1963. On the praxapostolos generally see J. Mateos, "La célébration de la parole dans la liturgie byzantine, Etude historique», OCA CXCI, Rome 1971, p. 128-29, 134-35. 39. The passage numbers, incipits and day designations are largely, but

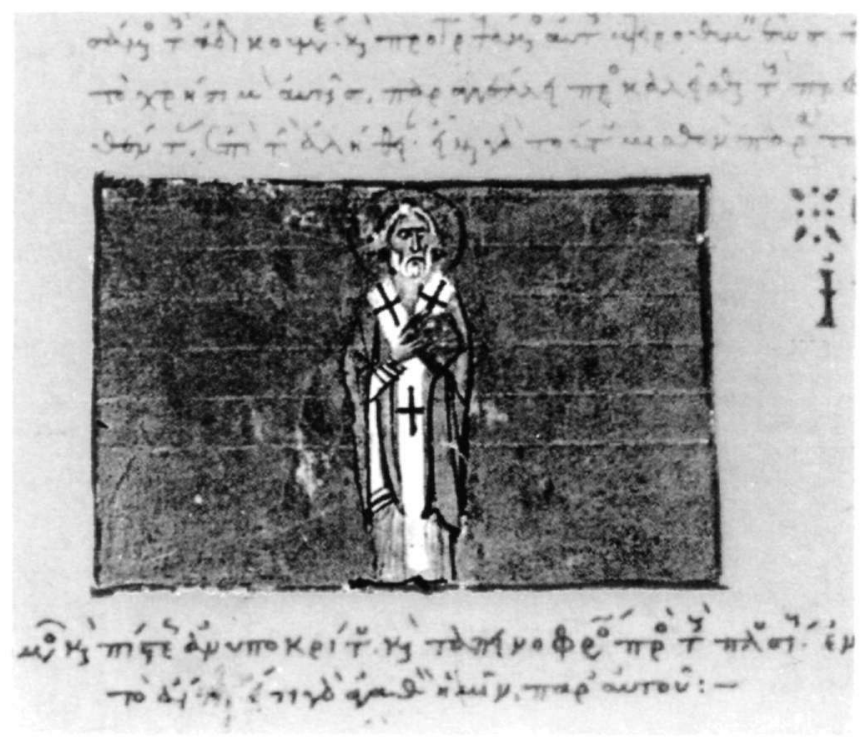

Fig. 9. Mt. Athos, Pantokrator Monastery Library, cod. 234, fol. 83v: James.

variation, so that the letters sit heavily on the page. The scribe also suppressed long strings of connected letters. Doublets, triplets and solitary letters predominate, and the longer strings that any leaf will contain fail to soften the effect of a discontinuous series of bold forms (fig. 1, line six opens on seven connected letters). The scribe has found the elusive minuscule counterpart for the uncial used in the Gospel lectionary even as late as the eleventh century. It is a commanding piece of writing. Within the list of related manuscripts two parallels exist. The script of the Harvard Psalter (fig. 3) is likewise bold, open, and marked by a limited use of ligatures, but even closer in execution to the Walters Praxapostolos is the script of the Gospel book in Geneva (fig. 4). Along with the various characteristics mentioned, the letters in the Gospel book are proportioned entirely like those of the Praxapostolos. The scribe's note at the top of the leaf («On the holy and great Sunday [of Easter]») means that he annotated the book for use in church, though by the twelfth century apparatus ostensibly added to facilitate liturgical reading might be found in copies made for individual study and inspiration ${ }^{40}$.

not entirely, the work of a hand other than the main scribe's; see the appendix for discussion. The $\alpha \varrho \chi \eta^{\prime}-\tau \varepsilon \dot{\lambda} \partial \varsigma$ designations are original. 40. A. Weyl-Carr, «Diminutive Byzantine Manuscripts», Codices Manuscripti 6 (1980), p. 130-36; J. Anderson, «A Twelfth-Century Instance of Reused Parchment: Christ Church College, Wake Gr. 32», Scriptorium 44 (1990), p. 213-16. 


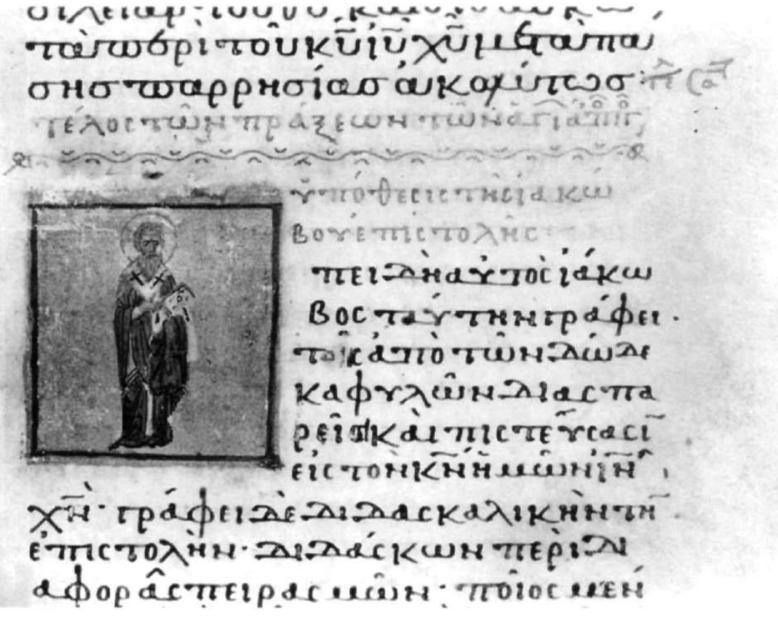

Fig. 10. Baltimore, Walters Art Gallery, cod. 533, fol. 89: James.

The handwriting of the Praxapostolos is stable throughout the manuscript, with the exception of a lapse in quire 32, fols. 254-256 (fig. 2). What happened on the three leaves is a matter for conjecture. What is certain is that the result had no consequence for the book's user, who would not have been even mildly inconvenienced. The effort required to reconstruct the circumstances underlying the scribe's brief change in manner can be justified in light of what may be revealed about how the Praxapostolos was made. The cursive is confined to the end of a single quire. Owing to the present state of binding, it is not immediately apparent how the leaves were gathered, but stubs appear between fols. 249 and 250 and again between 254 and 255. Stubbing is unusual for the Praxapostolos and suggests that single leaves were combined with bifolia in this gathering. The cursive text is undoubtedly contemporary with the rest of the Praxapostolos, since the two leaves in cursive contain illustrations entirely like the others $(254 \mathrm{v}, 255 \mathrm{v}$ : fig. 2). In addition, one of the folios with cursive traits (fol. 253) appears to be conjoint with another written in the liturgical minuscule (fol. 252). There is no reason to suppose that the leaves are the work of another scribe, let alone later work. The explanation for the change must be sought in an upset to the scribe's routine. Something happened that may have required removing and rewriting leaves, or possibly stretching the text to bridge two parts. The absence of rubrication suggests a certain hastiness, for the scribe used only brown ink, even for those passages he otherwise wrote in red. The format for illustration likewise changed. Instead of illustrations confined to blocks indented into the text, the two on fols. $254 \mathrm{v}$ and $255 \mathrm{v}$ (fig. 2) appear within column-length breaks. The pair of miniatures makes

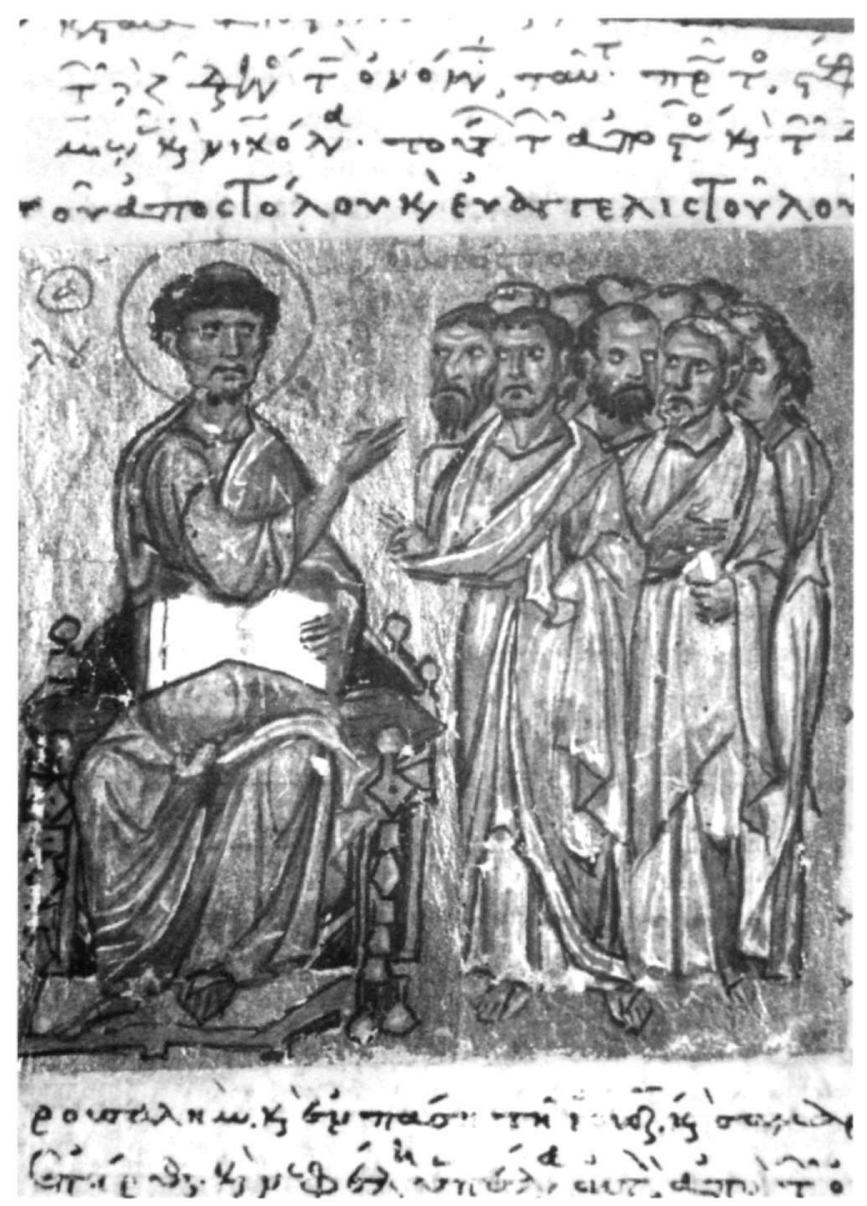

Fig. 11. Mt. Athos, Pantokrator Monastery Library, cod. 234, fol. 52v: Luke and Apostles.

the Pauline Epistle to the Thessalonians the only book illustrated with two portraits. Finally, a note on the script. The cursive depends on superficial differences between thick and thin strokes and on angularity. The pi becomes two stout strokes capped by a thin one that emphasizes the formal contrast; similarly, zeta and other letters tend to be more angular in nature. The scribe allows his letter sizes to vary. Owing in part to the slant and the long circumflex mark, the lines seem to hurry across the page. The manner of writing in question bears some similarity to that of the Codex Mavrocordatianus. It can also be related to the beautiful calligraphy found in the Vatican copy of the sermons of James the Monk, a parallel outside the group that supports the midcentury dating of the manuscript ${ }^{41}$.

41. Vat. gr. 1162: I. Hutter and P. Canart, Das Marienhomiliar des Mönchs Jakobos von Kokkinobaphos, Zurich 1991; J. Anderson, «The 
The scribe's routine appears to have been thrown off by indecision regarding divisions in the Praxapostolos text ${ }^{42}$. The praxapostolos was, as late as the Middle Ages, a scriptural text without a fixed sequence of books ${ }^{43}$. There were five clusters of writings: Acts, the Catholic Epistles (JamesJude), Pauline Epistles written to churches (Romans-Thessalonians), Pauline epistles to individuals (Timothy, Titus, Philemon), and the book of Hebrews ${ }^{44}$. The shift to cursive in the Walters Praxapostolos surrounds a change in units. This fact becomes significant when one compares the order of epistles in three of the works under discussion: the Walters Praxapostolos, Paris. suppl. gr. 1262 and the Pantokrator Miscellany (cod. 234).

$\begin{array}{lll}\begin{array}{l}\text { Baltimore } \\ \text { James }\end{array} & \begin{array}{l}\text { Paris } \\ \text { James }\end{array} & \begin{array}{l}\text { Pantokrator } \\ \text { Romans }\end{array} \\ \begin{array}{l}\text { I-III John } \\ \text { Jude }\end{array} & \begin{array}{l}\text { I-II Peter } \\ \text { I-III John } \\ \text { Jude }\end{array} & \begin{array}{l}\text { I-II Cor } \\ \text { Galatians } \\ \text { Ephesians } \\ \text { Philippians } \\ \text { Colossians }\end{array} \\ & & \text { I-II Thess } \\ \text { Romans } & \text { Romans } & \\ \text { I-II Cor } & \text { I-II Cor } & \\ \text { Galatians } & \text { Galatians } & \\ \text { Ephesians } & \text { Ephesians } & \\ \text { Philippians } & \text { Philippians } & \\ \text { Colossians } & \text { Colossians } & \\ \text { I-II Thess } & \text { I-II Thess } & \\ & \text { Hebrews } & \\ \text { I-II Timothy } & \text { I-II Timothy } & \text { I-II Timothy } \\ \text { Titus } & \text { Titus } & \text { Titus } \\ \text { Philemon } & \text { Philemon } & \text { Philemon } \\ \text { Hebrews } & & \text { Hebrews } \\ & & \text { James } \\ & & \text { I-II Peter } \\ & & \text { I-III John } \\ & & \text { Jude }\end{array}$

\footnotetext{
Illustrated Sermons of James the Monk: Their Dates, Order, and Place in the History of Byzantine Art», Viator 22 (1991), p. 69-120. 42. The texts affected are, beginning on fol. 254, Col. 4:12 to the end of the Epistle, through the colophon, the preface to I Thess, and I Thess 2:5a. At fol. 257 the scribe resumed the liturgical uncial. 43. B. Metzger, The Canon of the New Testament. Its Origin, Development, and Significance, Oxford 1987, p. 297-98; H. Gamble, Books and Readers in the Early Church: A History of Early Christian Texts, New Haven 1995, p. 59-66.
}

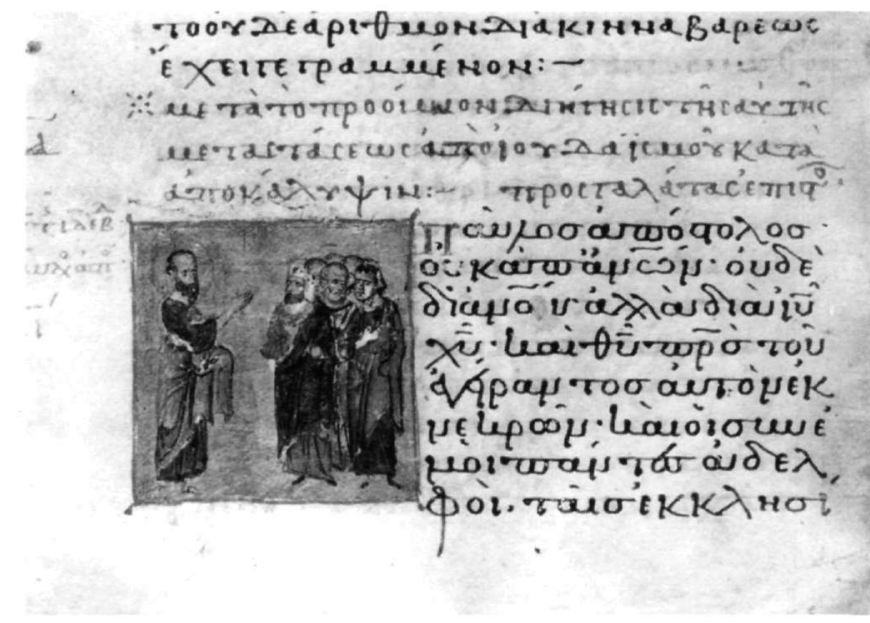

Fig. 12. Baltimore, Walters Art Gallery, cod. 533, fol. 216v: Paul and the Galatians.

The order in the Paris and Baltimore manuscripts is nearly the same, and both contain some of the apparatus relating to liturgical use. The order of books found in other collections of Epistles annotated for use in the service supports a view of the basic sequence in the Paris and Baltimore manuscripts as liturgical ${ }^{45}$. The clearly different arrangement of books in the Pantokrator Miscellany is that of a manuscript not intended for use in church, a fact that its content and style of writing proclaim. But even when the two liturgical versions are compared, the order is not exactly the same. In the Paris manuscript Hebrews falls after II Thessalonians, but it is the final book in the Walters Praxapostolos, where it was copied after Philemon, the place it holds in the Pantokrator Miscellany. As the scribe of the Walters Praxapostolos neared the end of one unit of text, something happened that briefly upset his balance. If the scribe were merely copying another manuscript, the upset would likely not have occured. It appears, therefore, that the scribe was engaged in assembling the Praxapostolos, arranging the text and apparatus to suit the patron's needs.

44. W. Hatch, «The Position of Hebrews in the Canon of the New Testament», Harvard Theological Review 29 (1936), p. 133-151, surveyed the question among a wide range of text types; his findings conform the status of Hebrews but do not elucidate the problem that arises in the present instance.

45. From the Vatican Library, see codd. 360, 363, 367: R. Devreesse, Codices Vaticani graeci, II, Codices 330-603, Vatican City 1937, p. 4647, 50-51, 55-57. 


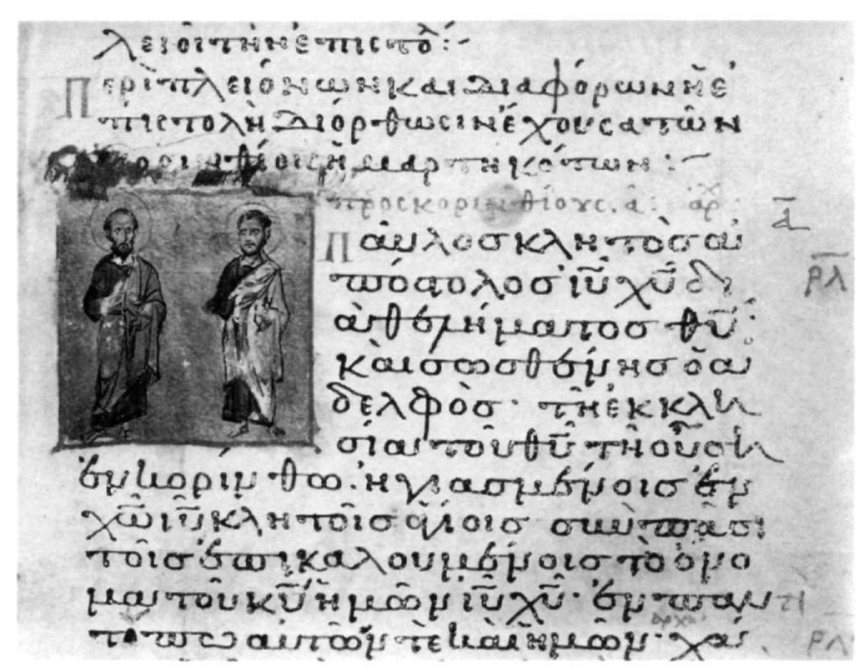

Fig. 13. Baltimore, Walters Art Gallery, cod. 533, fol. 165: Sosthenes and Paul.

The apparatus in the Walters Praxapostolos likewise suggests an ad hoc compilation, particularly when compared against that of the Paris. suppl. gr. 1262. Both manuscripts contain what is called the Euthalian apparatus, a set of titles, prefaces, subscriptions, and count of the amount of text in the biblical book (the stichoi) ${ }^{46}$. After finishing the transcription of the Catholic Epistles and Pauline epistles to the churches (James-II Thess) the scribe of the Walters Praxapostolos stopped adding the colophons and stichometry at the ends of the books. At the same point, the start of I Timothy, he began appending the lists of section titles (kephalaia) to the beginnings of the books, as they are often found in copies of the Gospels. The Paris Praxapostolos also contains the Euthalian apparatus, but its scribe did not interrupt the apparatus after II Thessalonians; the transition is seamless. A second change in transcription reinforces the indecision surrounding the placement of $\mathrm{He}$ brews in the Walters Praxapostolos. The scribe of the Baltimore manuscript was tight with parchment; he transcribed the various texts one right after the other leaving no spaces. That is, except after Philemon, at the end of which (fol. 288) he left the rest of the leaf blank, though only about five lines. He began the prefatory materials for $\mathrm{He}$ -

46. Metzger, op. cit., p. 298, discusses stichometry, but the numbers he gives do not, with one exception, agree with those in the Walters Praxapostolos. The numbers in the Paris and Baltimore manuscripts essentially agree with one another and approximate the edition in Migne, $P G$ 85, col. 716-20, 698-699 (Pauline Epistles agree but Catholic do not). brews on the verso in a slightly hurried style; then, at the end of the prefatory materials, he left a full two-thirds of a leaf empty before starting Hebrews at the top of fol. 291. The departures in format and script reveal the hesitation over the placement of the book of Hebrews within the liturgical sequence. Though utterly inconsequential for the book's reader, the changes point to a manner of transcription that has the scribe arranging contents to meet the user's needs.

As N. Wilson once observed, there was probably no book trade on medieval Constantinople, at least in the sense that we would understand the term ${ }^{47}$. Many books were made by an individual who was presented with the exemplar and paid to copy it. The individual might be a monk, a priest, deacon or a bureaucrat. A large office stocked with books was not a requirement; the only requirements were care in transcribing and good penmanship. The differences among the three surveyed copies of Acts and Epistles suggest that a model and the knowledge to rearrange its contents marked the group under discussion. The Pantokrator Miscellany extends the hypothesis. The scribe of the Miscellany wrote in a short, clipped manner that stands apart from the liturgical minuscule of the Walters Praxapostolos and Geneva Gospels. Among the works enumerated it finds a strong parallel in the Basel New Testament (figs. 6, 11). The contents of the Miscellany, which have not yet been compiled despite the book's very considerable importance, point to an unusual commission $^{48}$. In addition to the psalms and New Testament, the manuscript contains a selection of sermons of Gregory of Nazianzen, digests of Church councils and synods; selections from writings by John of Damascus, Athanasius, Psellos and others. Some of the writings are in dialogue form, as if to prepare the reader for debate or teaching by means of pithy summaries of complex issues. Other writings in the collection show a need to grasp canon law. The Miscellany looks like a manuscript compiled for a ranking cleric who needed a bookshelf of theological and legal texts at his fingertips; its content may suggest someone of episcopal status concerned with teaching, discipline and administration. As a compilation, the Miscellany implies a scribe able to assemble florilegia, possibly from a specialized library or a book collection of some richness. The scribe of the Walters Praxapostolos was also

47. N. Wilson, Books and Readers in Byzantium, Byzantine Books and Bookmen, Washington 1975, p. 1.

48. The closest thing to an inventory, and it is far from complete, is the listing in Pelekanides et al., Treasures of Mt. Athos, III, p. 283-87. 


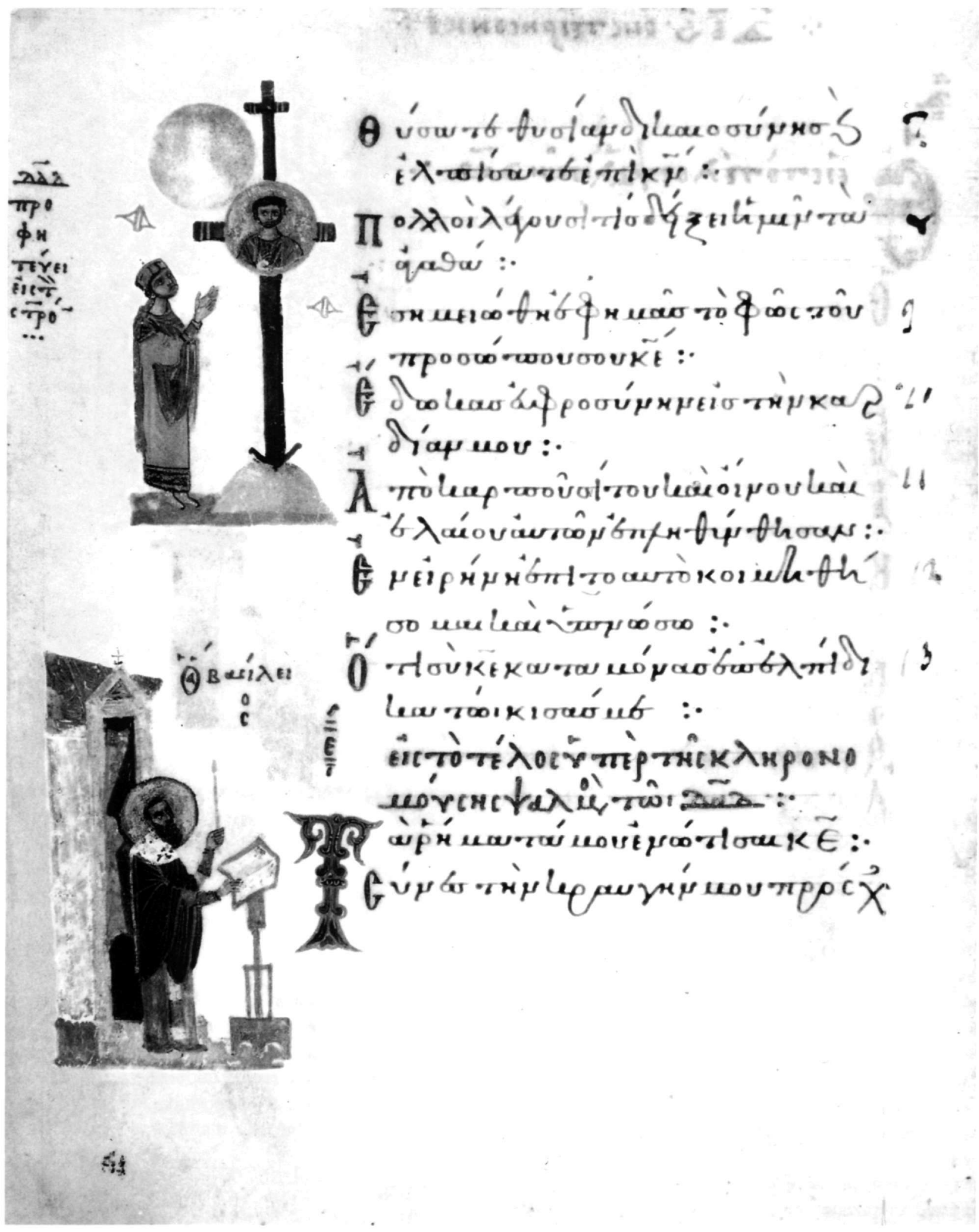

Fig. 14. Rome, Vatican Library, Barb. gr. 372, fol. 9v: St. Basil reading. 
making a compilation when he arranged the Epistles. The differences in content, which at first suggest that the group of related manuscripts is merely an art historical construct based on painting style, reflect the circumstances behind the production of the group of scribes and illuminators active for over a generation.

\section{The Illustrations and Liturgical Imagery}

Over the last decades the study of subject matter has shifted ground. No longer content with identifying the subject, its textual correlatives and visual antecedents, art historians now seek to uncover the picture's content as it was perceived by its beholder. The categories available to begin describing a contemporary's experience are necessarily few and inexact. A medieval image might be considered didactic, liturgical or devotional, depending on the balance of scale, size, location and composition. The book illustration survives imbedded in a context rich with interpretative clues. In the case of the Walters manuscript, the function was liturgical. Therefore, the miniatures are liturgical -but what does this mean? How does knowledge of the manuscript's use enrich our understanding of what seems to be a rather simple set of portraits? We are in the unusual position of having both question and answer, but not the steps to get from one to the other. A distinct mental image of the book in use might be one place to begin recovering the relationship of image to beholder. For the purpose, we can use an eleventh-century miniature. The scene (fig. 14) centers on St. Basil and illustrates Ps. 5:3, «In the morning thou shall hear my voice». The illuminator depicted Basil at a lectern reading to the implied audience collected within the church at his back; perhaps we are expected to envision an early morning service conducted in a narthex lit only by lamps. As he chants the office, Basil stands erect, at nearly arm's length from the book, and holds a candle for the light he needs to follow the words. The large and boldly written letters of the Walters Praxapostolos made it possible, even in poor light, to read aloud to a group without stumbling. Since the manuscript was made for public performance, the illustrations seem gratuitous: only the reader could see them. They could not enhance performance in the way that the diagram in a schoolbook might contribute to the understanding of a passage in Euclid's Elements. The implied tension may be an outcome of associations surrounding the categories. The terms «devotional» and «didactic» suggest the individual's gaze fixed in private communion with the object of veneration or study, whereas «liturgical» summons up a world of corporate acts that serve publicly to bind a community of

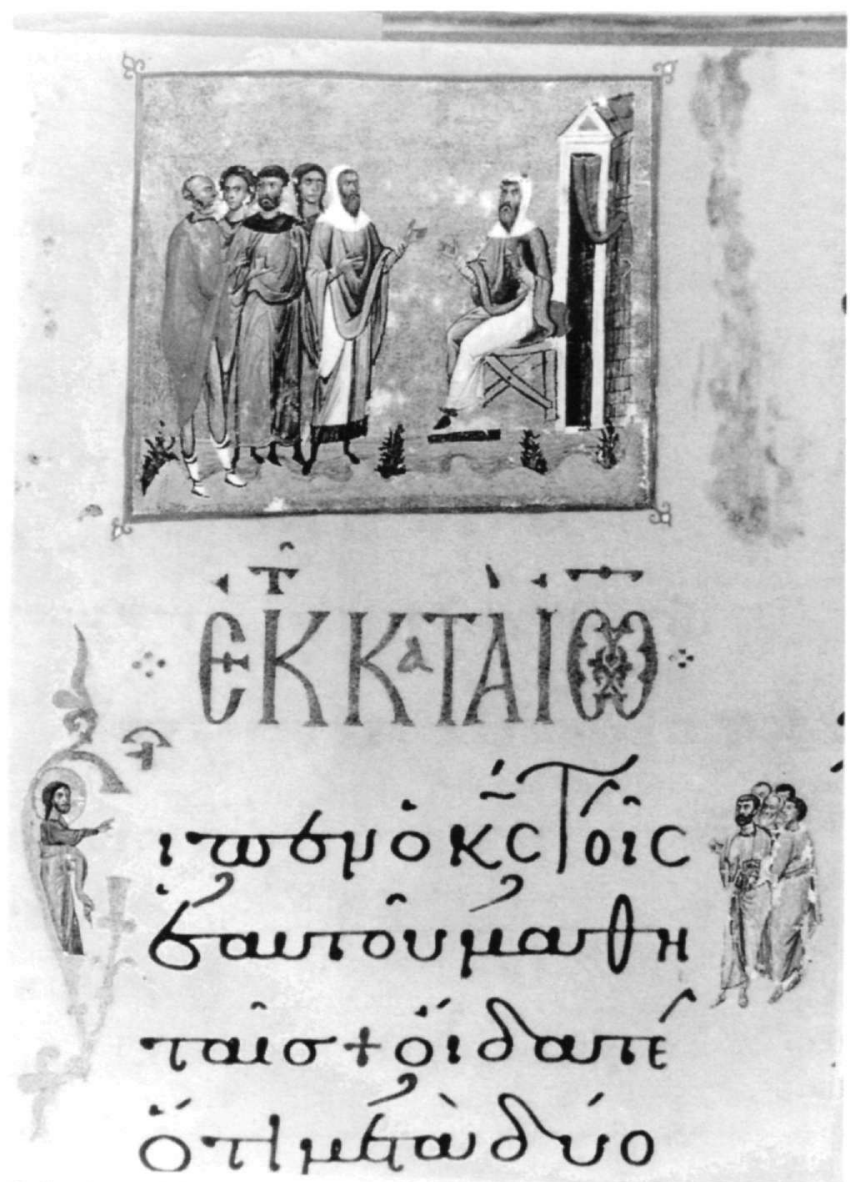

Fig. 15. Mt. Athos, Dionysiou Monastery Library, cod. 587, fol. 54.

believers. But where is St. Basil's audience in the Psalter? Perhaps its absence can be construed as tacit acknowledgement of the moment when the community of believers receded to leave only the supplicant before God. The message of the Praxapostolos' illustrations was emphatically directed to the reader; moreover, the illustrations communicated at two levels. Both were in a sense private, in as much as they served to establish the reader in his role.

At one level the illustrations of the Praxapostolos are part of a non-biblical apparatus that stood outside the realm of performance. The miniatures accompany the various writings that informed the reader about the authorship of the text, its date and place of composition, and so on $^{49}$. As if to demonstrate the point, the illuminator located the first

49. The relevance of non-biblical writings to illumination was explored in the contemporary studies of Nelson, op. cit. (note 11), and Galavaris, Prefaces. 
three portraits and two subsequent ones within the prefatory essays, instead of at the start of the epistles ${ }^{50}$. By this unusual position the illuminator revealed the extent to which he conceived of the portraits as information of a kind necessary for a full appreciation of the Bible. The generally full-length depictions seem especially welladapted to the purpose. From his white beard and receding hairline, we learn that John was an old man (fig. 1), but that Paul and his collaborator, Sosthenes, were relatively young at the time they wrote (fig. 13). The authors' dress also contributed to the reader's appreciation; the illuminator differentiated it broadly into two types, the ancient himation and the contemporary costume of a bishop. Use of the himation appears to give some authors an apostolic authority (fig. 12), whereas the episcopal regalia recalls those who settled in and took responsibility for the daily affairs of urban centers and their surrounding populations: Timothy, bishop of Ephesus, and James, bishop of Jerusalem (fig. 10). Standing portraits are an ancient genre widely used in church decoration, icon painting, and various branches of manuscript illustration, and to comment further would be to overburden this staple of Byzantine art. The simple answer to the question, What purpose did the miniatures serve? is that portraits provided knowledge the Byzantine readers felt to be helpful (but that modern ones may find superfluous, if not misleading or thoroughly erroneous). A more complicated message resides at another level. To get at it, it is necessary to know that the information presented to the reader of the Walters Praxapostolos has been slanted in a certain direction.

The choice of portrait formula, the standing figure, results from the illuminator's conscious exclusion of one, possibly two, far more obvious choices. In evaluating the illuminator's decision it is worthwhile recalling that with the exception of Acts the Praxapostolos is a collection of letters. The prefaces, opening verses and colophons leave no doubt about the literary genre. S. Der Nersessian noted that the illuminator was aware of the content of the salutations and brought the illustrations into line with them; when a second writer is mentioned the portrait will reflect joint-authorship, as happens in the image of Paul and Sosthenes at the start of I Corinthians (fig. 13) ${ }^{51}$. Coordination of text and image proves that the illuminator recognized the kind of literature he was working with. With this fact can be combined another: Byzantine illuminators of the Middle Ages had no trouble depicting the creation of a letter or an exchange of letters. When doing so they painted a seated figure writing and a servant bearing away the rolled and sealed scroll ${ }^{52}$. Examples may not

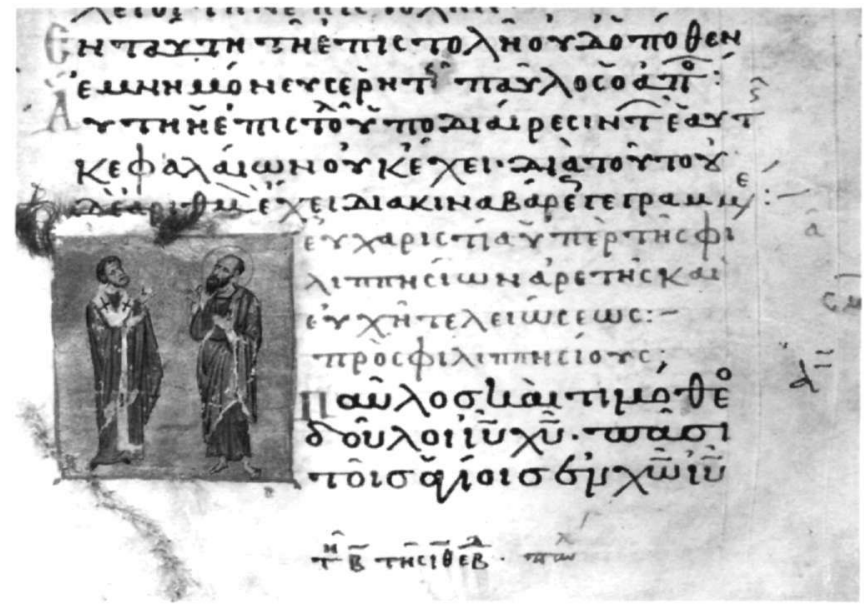

Fig. 16. Baltimore, Walters Art Gallery, cod. 533, fol. 239: Timothy and Paul.

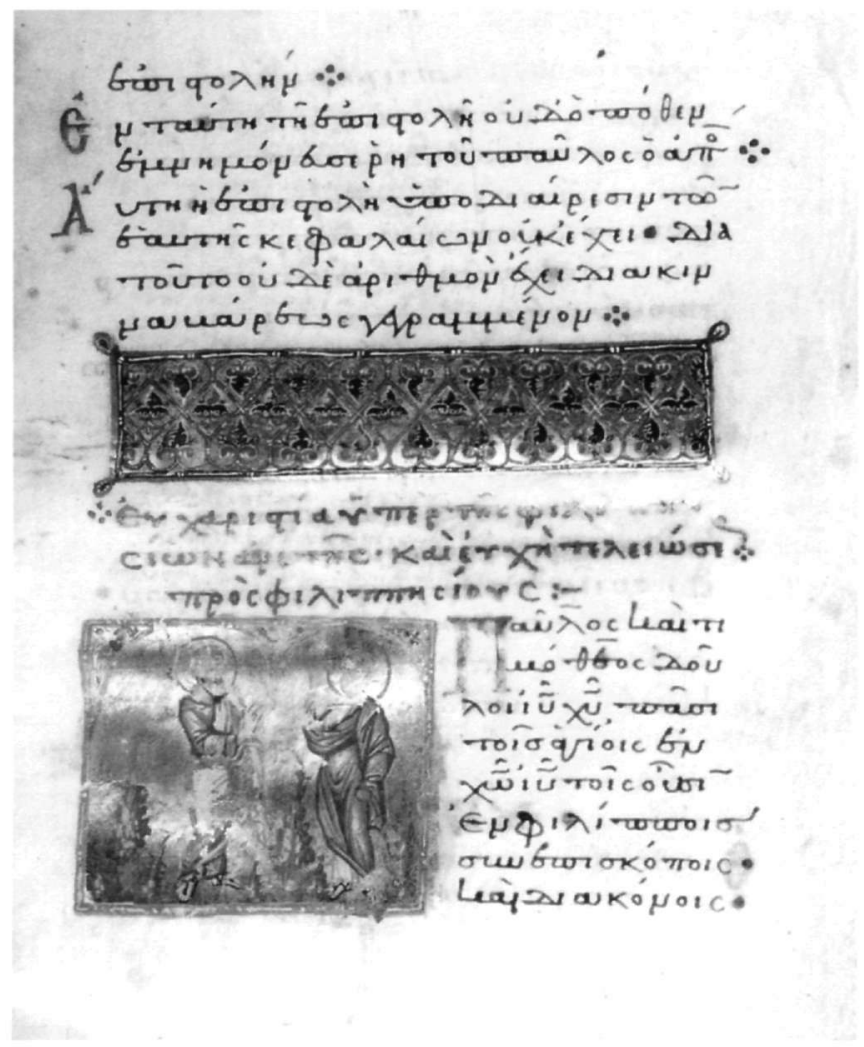

Fig. 17. Mt. Sinai, Monastery of St. Catherine, cod. 275, fol. 245: Timothy and Paul.

50. John (fol. 125) and Paul (fol. 254v).

51. Der Nersessian, Praxapostolos, p. 45.

52. Examples from medieval copies of the Old Testament, New Testament and homiletic writings include: Rome, Biblioteca Apostolica 


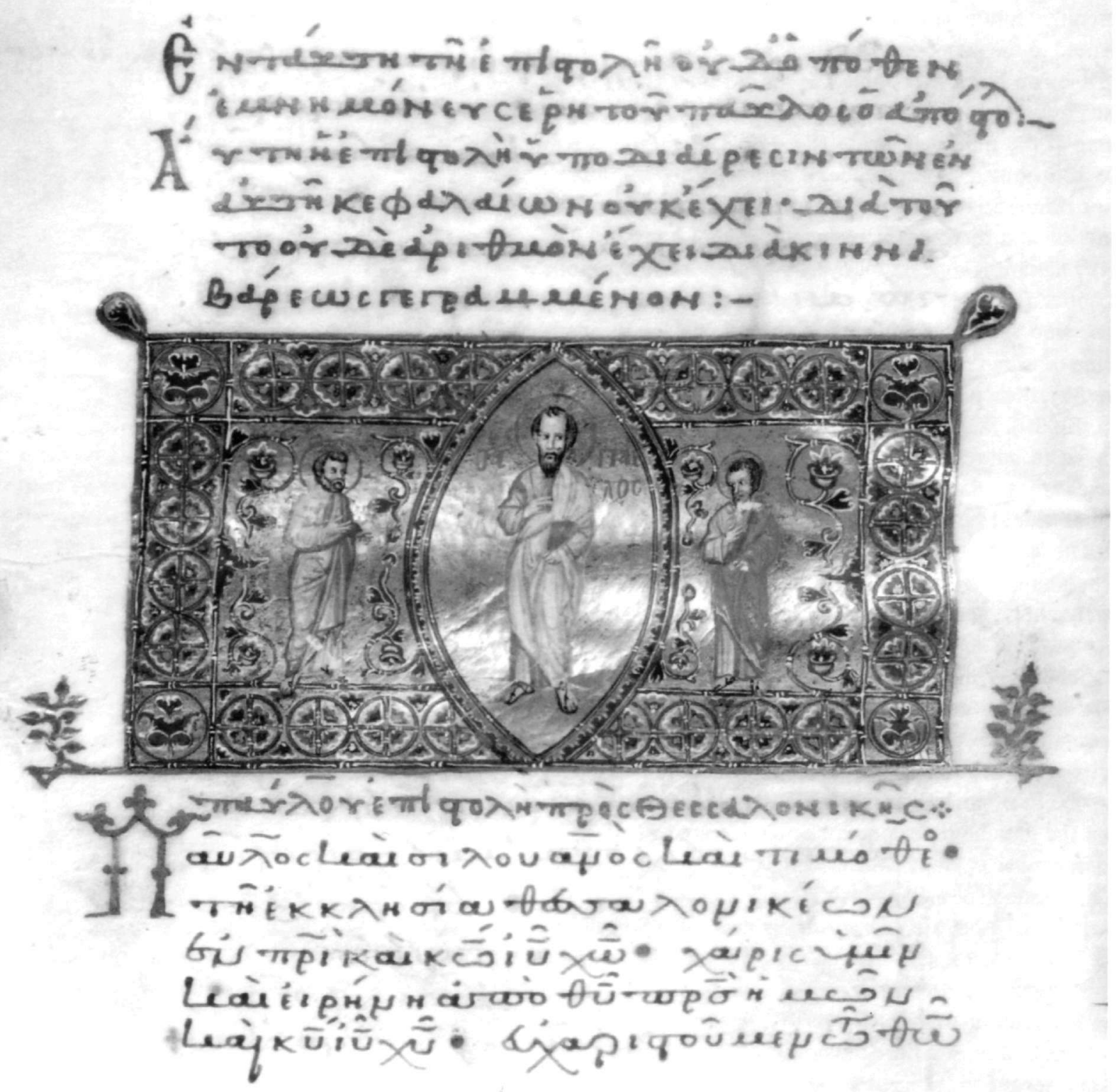

Fig. 18. Mt. Sinai, Monastery of St. Catherine, cod. 275, fol. 270v: Timothy, Paul and Silas. 
be common, but they are sufficient to support the claim that the illuminator of the Praxapostolos considered and then rejected the exchange-of-letters composition. No doubt surrounds the illuminator's decision to avoid the much more common form of author portrait, the writer at work in his study. A number of illustrated copies of the epistles, including the relevant section of the Pantokrator Miscellany, contain portraits that show the author seated at a desk with his books and scrolls, writing or pausing to reflect $^{53}$; such portraits were either adapted from or grew up alongside Evangelist portraiture. A twelfth-century portrait of Paul in Athens combines the letter-writing genre with the seated author and teacher in a way that demonstrates the range of possibilities open to an illuminator ${ }^{54}$. The evidence of portraits found in manuscripts stylistically related to the Praxapostolos along with the portrayal of St. John show that the illuminator of the Baltimore manuscript was aware of various portrait types. The illuminator painted three portraits of John, each slightly different. In the first instance the Saint walks to the right holding open an enormous book (fig. 1). The pose is found in portraits of the Evangelists Matthew and John in two tenth-century manuscripts ${ }^{55}$. The second portrait has the author standing in a twisting pose that might recall evangelist portraiture but need not necessarily do $\mathrm{so}^{56}$. The last of the three again has John turned to the text holding an open book, perhaps an independent variation on the type of John

Vaticana, cod. Ross. gr. 137, fols $4 \mathrm{v}$ and 5 (latter in Galavaris, Prefaces, fig. 95); and cod. 747, fol. 12 (Th. Uspenskij, «L'Octateuque de la Bibliothèque du Sérail à Constantinople», Izvestija Russkago Arheologiceskago Instituta v Konstantinople 12 [1907], pl. VIII, 9, 10: see also pl. VIII, 8, the same composition in Istanbul, Topkapi Sarayi, cod. 8, fol. 22v). Mt. Athos, Panteleimon Monastery Library, cod. 6, fol. 77v (G. Galavaris, Gregory Nazianzenus, fig. 147, and Pelekanides, et al., Treasures of Athos, I, fig. 304); and the Madrid Skylitzes, Biblioteca Nacional, cod. vitr. 26-2, e.g., fol. 75v: A. Grabar and M. Manoussacas, L'illustration du manuscrit de Skylitzès de la Bibliothèque nationale de Madrid, Venice 1979, fig. 76.

53. Tenth century: Oxford, Bodleian Library, cod. Canon. gr. 110: I. Hutter, Corpus der byzantinischen Miniaturenhandschriften, I, Oxford Bodleian Library, 1, Stuttgart 1977, p. 3-8, figs. 11, 12, 15, 18-20. Eleventh century: Washington, Dumbarton Oaks Collection, cod. 3: Der Nersessian, Psalter and New Testament, p. 155-83, figs. 33, 38, 42.

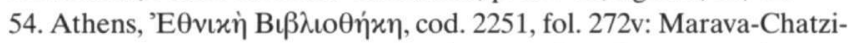
nicolaou and Toufexi-Paschou, Catalogue, II (1985), p. 82-93, fig. 182. 55. Paris, Bibliothèque Nationale, gr. 70, fols. 4c, 307v: J. Ebersolt, La miniature byzantine, Paris 1926, pls. XXX, 1, 4; and Vienna, Österreichischen Nationalbibliothek, theol. gr. 240, fols. 8v, 255v: P. Buberl and H. Gerstinger, Die byzantinische Handschriften, II, Die

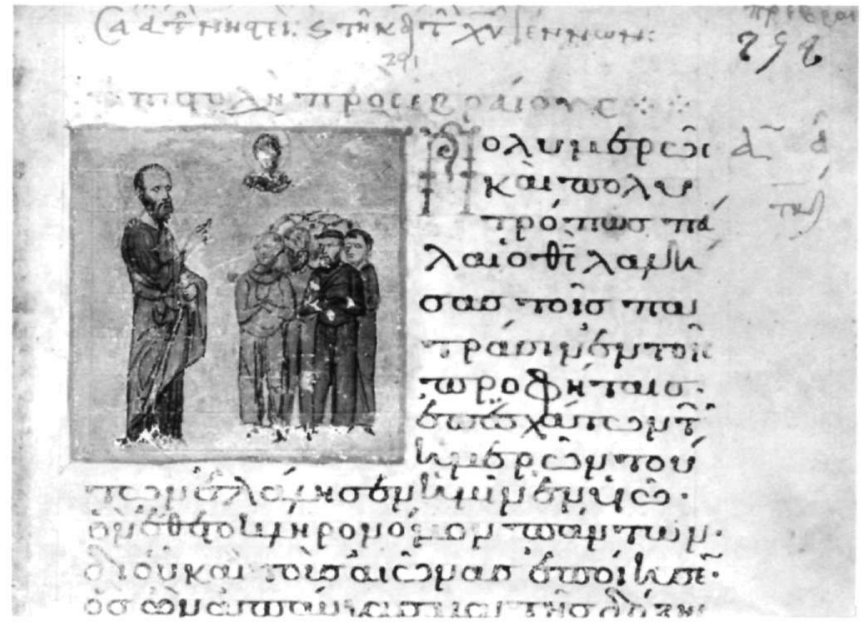

Fig. 19. Baltimore, Walters Art Gallery, cod. 533, fol. 291. Paul addresses the Hebrews.

walking, absorbed in his reading. The portrait showing John holding an open book is proper to Evangelists and sometimes proper to John specifically ${ }^{57}$. The illuminator chose to depict the author in a way that acknowledged his status as one of the Four Evangelists. Still, he did not do so in the most obvious way, by showing John sitting at a desk, as other illuminators facing parallel demands $\mathrm{did}^{58}$. Whatever the authors are doing in the Baltimore manuscript, they are decidedly not writing. The illuminator has, I be-

Handschriften des X.-XVIII. Jahrhunderts, Leipzig 1938, pls. II, 1, 4. But the pose was also used in the depictions of Mark and John in Mt. Athos, Iviron Monastery Library, cod. 247m: Pelekanides et al., Treasures of Mount Athos, II, Athens 1975, figs. 169, 170; in this manuscript John holds an open book but does not appear to walk (ibid., fig. 171). John appears holding the book and turned toward the writing with his knee bent in a marginal portrait in the Dumbarton Oaks Psalter-New Testament (Washington, Dumbarton Oaks Collection, cod. 3, fol. 260: Der Nersessian, Psalter and New Testament, figs. 37, 60 ). See also the processing Evangelists of Cod. Vat. gr. 756, fol. 11v: Galavaris, Prefaces, fig. 83.

56. See Mark in Paris, gr. 70, fol. 113v: Ebersolt, op. cit., pl. XXX, 2) or Luke in Vind. theol. gr. 240, fol. 157v: Buberl and Gerstinger, op. cit., pl. II, 3.

57. For entire groups of Evangelists represented more or less in this fashion see: Rome, Biblioteca Apostolica Vaticana, gr. 756, fol. 11: Galavaris, Prefaces, fig. 83.

58. The range and choice of portraits in an eleventh-century menologion at St. Catherine's show the association of Evangelist and the act of writing seated at a desk had become quite powerful: Mt. Sinai, Monastery of St. Catherine, cod. 500, fol. 302: Weitzmann and Galavaris, Mount Sinai: Illuminated Greek Manuscripts, fig. 215. 
lieve, made a choice and not simply followed a tradition ${ }^{59}$. The illuminator of the Walters Praxapostolos chose forms that allowed him to suppress the act of writing and to emphasize reading or speaking. The composition used for John has the Evangelist holding the great book looking as if he were reading from it (fig. 1). In two other miniatures the illuminator of the Praxapostolos acted to subvert the literary genre by showing the author delivering the text as a speech to an assembled crowd. In these miniatures Paul holds a scroll, the form of a rolled letter, and declaims dramatically (figs. 12, 19). The emphasis falls on the performance of the text, not its creation. In capturing the spirit of a book used as the source of public readings, the illuminator selected from types to create a liturgical imagery that spoke to the reader alone. He was not the first to spin the imagery of a performance text in this direction.

Among the examples that will put the illustration of the Walters Praxapostolos into a wider context is a late eleventh-century Gospel lectionary, Cod. 587 of the Dionysiou Monastery, Mt. Athos. The illustration for the Good Friday reading consists of two parts, one narrative and the other liturgical (fig. 15) ${ }^{60}$. In the framed miniature at the start of the text, the Jewish leadership gathers before the high priest Caiaphas. If the passage is read as an account of the series of episodes leading to Christ's execution, then the assembly before Caiaphas becomes the first event recounted ${ }^{61}$. It is a dramatic and pivotal moment, when suspicion and fear lead to an act that sets in motion the train of final events. No matter what its other functions, the framed miniature is a narrative book illustration in the traditional sense. The second illustration is the opening letter of the reading. In the initial Christ stretches forth his hand to address the disciples assembled across the column. Together, speaker and audience illustrate the opening words (Mt 26:2): «The Lord said to his disciples, 'You know that after two days Passover is coming...'». The content of Christ's utterance, the congruence of Passover and his passion, is not, cannot be, the substance of the illustration. That substance is the act of speech, and as such the illustration is one of many in which the formalized incipits, which mostly begin with «the Lord said...», became an object of the artist's attention ${ }^{62}$. As was true of the Walters Praxapostolos, the emphasis falls on performance: the text as Christ's speech. There are several points that need to be made about such images. The first regards the sudden and steep arc of popularity they enjoyed. The type has almost no forerunners in illumination prior to the middle of the eleventh century, when depiction of performance became common $^{63}$. Although passages in the lectionary begin «the Lord said», so obvious a cue failed for centuries to attract anything more than the occasional hand shown making a speech gesture. Because of the straightforward connection between illustration and opening words, the Gospel lectionaries offer a source of testimony obvious but not unique. The second point regards the diffusion of performance images throughout various writings used in
59. The two copies of the praxapostolos at Jerusalem (cod. Taphou 47: A. Weyl Carr, Byzantine Illumination 1150-1250. The Study of a Provincial Tradition, Chicago 1987, p. 235-6 and passim, fiche 5C1-4, 5D111) and Sinai cod. 275, discussed below, cannot be considered independent witnesses of a tradition of standing authors. Another contemporary manuscript containing the New Testament has standing authors, but they are unrelated and their treatment in groups divorced from the text differs from the approach taken by the illuminator of the Walters Praxapostolos: Madrid, Escorial Library, gr. 10.4.17, fols. 194v-196v: H. Buchthal, «A Greek New Testament Manuscript in the Escorial Library, Its Miniatures and Binding, Byzanz und der Westen», Studien zur Kunst des europäischen Mittelalters, ed. I. Hutter, Vienna 1984, pls. XXVII-XXIX. The idea of successive portraits separate from the writings recalls the illustration of the Apostles in another contemporary New Testament: Malibou, J. Paul Gety Museum, acc. no. 83, MB.68: R. Nelson, «Theoktistos and Associates in TwelfthCentury Constantinople: An Illustrated New Testament of A.D. 1133", The J. Paul Getty Museum Journal 15 (1987), fig. 21.

60. Mt. Athos, Dionysiou monastery, cod. 587: T. Masuda, $H$ Eixovo-

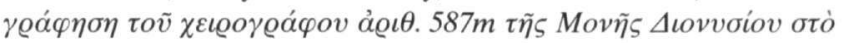
"A see also fols. 34v, 38v, 54, 66, 125, 143, 144v, 158v (Pelekanides et al., Treasures of Mt. Athos, I, figs. 212, 214, 225, 226, 246, 257, 259, 267). 61. The passage consists of Mt 26:2-20, Jn 13:3-17, Mt 26:21-39, Lk 22:43-45, Mt 26:40-27:2.

62. For some other examples see: Athens, National Library, cod. 68, fols. 43, 64, 123 (Marava-Chatzinicolaou and Toufexi-Paschou, op. cit. [note 10], figs. 471, 473, 476); New York, Pierpont Morgan Library, cod. M 639, fols. 22v, 94: K. Weitzmann, «The Constantinopolitan Lectionary Morgan 639", Studies in Art and Literature for Belle Da Costa Greene, ed. D. Miner, Princeton 1954, figs. 302, 319; Paris. suppl. gr. 27, fol. 17: Omont, Miniatures des plus anciens manuscripts grecs, pl. XCVIII. 63. Ninth-century examples occur in the Milan Gregory (Cod. Ambr. gr. $49-50$, pp. $4,65,119,156,209,214,342,344,354,383,384,437$, 453, 478, 492, 544, 568, 639, 652, 657, 660, 676, 694, 698t: A. Grabar, Les miniatures du Grégoire de Nazianze de l'Ambrosienne, Paris 1943, pls. II, VI, XII, XVI, XXIII, XXVII-XXXIII, XXXVI, XXXVII, XLI, XLII, LII-LIV, LVIII, LX, LXII). Contrast with the Paris Gregory (cod. gr. 510), in which the content of the text, not its delivery, is the principal responsibility of the illumination; Omont, Miniatures des plus anciens manuscrits grecs, pls. XX-LX. 


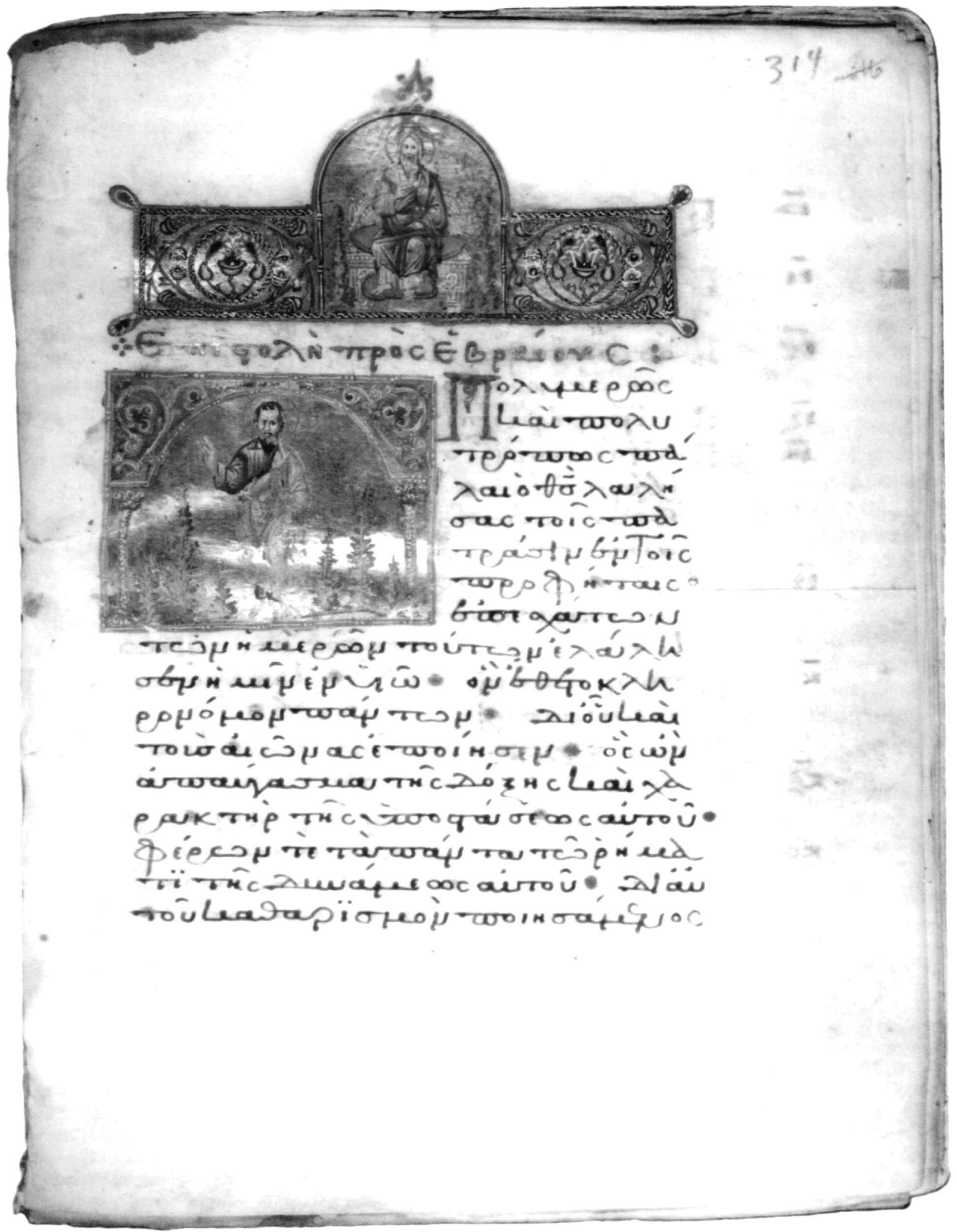

Fig. 20. Mt. Sinai, Monastery of St. Catherine, cod. 275, fol. 314: Ancient of Days, Paul. 
the Byzantine service. As G. Galavaris has noted, scenes of Gregory lecturing to an audience are one of the subjects often found in the eleventh - and twelfth-century selections intended for liturgical use ${ }^{64}$. In some cases, the depictions of Gregory teaching closely parallel the lectionary scenes showing Christ addressing the Disciples, or Paul lecturing the Galatians (figs. 12,15) ${ }^{65}$. In all such instances the illustration was designed to communicate with an individual, the reader, particularly at the moment when he lifted and opened the book to offer the day's reading. The illustration prepared him for the task he was about to undertake, which was a continuation of the apostolic tradition instituted by Christ and sanctioned by the Old Testament (figs. 14, 15). The clerical dress of some of the Praxapostolos authors would have served to reinforce the tradition.

The liturgical nature of the imagery in the Walters Praxapostolos develops in a moment of private contemplation. The reader is reminded that he is like the Apostle Paul addressing an audience (fig. 12). Contrasting evidence from a work created within the same sphere as the Praxapostolos reinforces the argument that Byzantine illumination, though seemingly restricted in visual range, was capable of considerable nuance of expression. The portraits in the Pantokrator Miscellany divide along a number of lines, but the emphasis clearly falls on writing and dictation, that is, on the authority of the written word ${ }^{66}$. An additional emphasis falls on the seated teacher and on evangelism as a community activity conducted in a fraternal atmosphere (fig. 11) ${ }^{67}$. Handwriting style and content proclaim the Miscellany to be a book different from the Praxapostolos. The Miscellany was intended as a clerical bookshelf in one volume, not a service manual. The scriptural books were supplemented by others that would serve as guides when explaining belief or settling disputes. The miniatures in the Walters Praxapostolos served an individual in his conduct of the liturgy.

64. Galavaris, Gregory Nazianzenus, p. 27-37.

65. Paris, Bibliothèque Nationale, gr. 533 , fols. $47 \mathrm{v}, 70,91,146,154$, $158 v, 218 v, 236,251,276 v$ ): Galavaris, Gregory Nazianzenus, figs. 242, 244, 246-49, 252-55.

66. See fols, 23v, 31, 43, 63, 67, 88v, 258: Pelekanides et al., Treasures of Mt. Athos, III, figs. 242-44, 246, 247, 252, 256.

67. For the seated teacher see fols. $52 \mathrm{v}, 84 \mathrm{v}, 86 \mathrm{v}$ : Pelekanides et al., Treasures of Mt. Athos, III, figs. 245, 247, 249, 250; for a fraternal spirit see the portraits on fols. 23v, 31, 43, 52v: ibid., figs. 242-45.

68. Der Nersessian, Praxapostolos, p. 40 (see note 7).

69. Weitzmann and Galavaris, Mount Sinai: Illuminated Greek Manuscripts, op. cit. p. 110-16, figs. 341-348 (see note 19).

\section{A Copy of the Walters Praxapostolos on Mt. Sinai}

When S. Der Nersessian published the Walters manuscript, she called attention to parallels between it and a praxapostolos at St. Catherine's Monastery on Mt. Sinai, cod. 275. She characterized the two manuscripts as «closely allied", but did not explore the nature of the alliance ${ }^{68}$. Clarifying the relationship is the final task I wish to undertake before offering some concluding remarks. The most direct approach to the miniatures lies through the relative dates of the manuscripts and then the relationship of their written contents. In the catalogue of the illuminated manuscripts of St. Catherine's, K. Weitzmann and G. Galavaris date the Sinai Praxapostolos to the eleventh or twelfth century ${ }^{69}$. Although the script recalls work of the twelfth century, in particular a slightly cursive version of the liturgical minuscule, the miniatures were not painted in the twelfth century; they are work of the later thirteenth or the fourteenth century. The parallel portraits to Philippians (figs. $16,17)$ offer a contrast of twelfth-and thirteenth-century styles. The figures in the Walters Praxapostolos are of limited corporeality, their movements of restricted scope. The authors in the Sinai miniature were rendered with so much contrast that their garments seem to have been inflated. Partly as the result of the increased plasticity, the gestures are heightened and the positions of the legs better defined, so the miniature creates an impression of greater vitality. The Sinai portraits of Paul and his companions Timothy and Silas (fig. 18) show powerful, bearded men who gaze piercingly with small eyes. Together, the strong contrasts, extreme plasticity and emotional intensity signal the art of the second half of the thirteenth century. Elements of the style are found in the portraits that the Patriarch Athanasios I (1289-93) had made and inserted in the Gospel book now Princeton, University Library, Garrett $2^{70}$.

The chronological relationship between the Sinai Praxapostolos and the example in Baltimore limits the number of possible relationships that could account for the close alliance Der Nersessian noted in their illustration. One is

70. Greek Manuscripts from American Collections, p. 176-79; H. Buchthal and H. Belting, Patronage in Thirteenth-Century Constantinople. An Atelier of Late Byzantine Book Illumination and Calligraphy, DOS XVI, Washington 1978, p. 62. Among undated works attributed to the second half of the century and resembling the Praxapostolos are Gospels in Athens and Oxford: Athens, National Library, cod. 118 (Marava-Chatzinicolaou and Toufexi-Paschou, op. cit., 44-45, figs. 66, $68,70,73$ ); Oxford, Bodleian Library, E. D. Clarke 6 (Hutter, Corpus, I/1, 94-96, figs. 358-365). 
that the Baltimore manuscript served as the source for Sinai cod. 275 . This possibility can be evaluated by comparing the books' contents ${ }^{71}$. The contents and their order are the same, including a number of details that combine to offer a compelling case for a model-and-copy relationship. The scribe of the Baltimore manuscript wrote the $\alpha \varrho \chi \dot{\eta}$ and $\tau \varepsilon \dot{\lambda} \lambda \circ \varsigma$ of the lectionary system but not the complete marginal apparatus, which was added later along with the tables at the end (fols. 314-60v). The Sinai Praxapostolos reflects the state of the Baltimore manuscript prior to the addition of the marginal prompts and numbers. The changes in Euthalian apparatus discussed above - the presumably unique inconsistencies in the Baltimore scribe's transcription that set his work apart from the Paris. suppl. gr. 1262 are reproduced in the Sinai manuscript. The short subscriptions found in the Sinai Praxapostolos change in lockstep with those in the Baltimore manuscript. The Baltimore scribe omitted the stichometry at the end of III John, probably inadvertently, and then ceased entirely at I Timothy. The Sinai Praxapostolos reproduces these changes, including the accidental omission at III John. The Baltimore scribe's omission of colophons and stichometry was accompanied by the addition of neat lists of kephalaia, and the slight variations in format were traced to his having compiled the work as he went along. The lists appear in the same place in the Sinai Praxapostolos, though it shows no changes in script or format. The Sinai Praxapostolos thus appears to be an apograph of Walters cod. 533. The reason for the choice of the Baltimore manuscript as the source for so common a text was most likely its illustration.

Although the illustrations of the twelfth-century manuscript led to its being selected for copying, the thirteenthcentury illuminator did not simply reproduce what lay before him. The patron wanted a more lavish work, and this desire led to the most obvious differences between the two cycles. In place of the single lines that frame the portraits in the Walters Praxapostolos the illuminator of the Sinai manuscript substituted wide rectangles of faux-enamel (fols. 101, 111v, 131, 227), arches supported on columns (fols. 91v, 119v, 129, 173v, 254v, 256v, 286, 296v, 304, 309, 314; fig. 20), or even more elaborate confections (fols. 139,

71. I know the manuscript through a microfilm in the Library of Congress, Washington, D.C.

72. Walters cod. 533, fol. 262v (Der Nersessian, Praxapostolos, fig. 10) and Sinai cod. 275, fol. 279v (Weitzmann and Galavaris, Mount Sinai: Illuminated Greek Manuscripts, fig. 374 [see note 19]).

73. They are the illustrations to: Acts, II John, Ephesians, II Thess, II Tim. 270v, 279v; fig. 18). When reproducing the headpiece portrait of Timothy, Paul and Silas (figs. 2, 18), the Sinai illuminator painted the figures full length in a large rectangle, but added a frame around Paul that continued the separation implicit in the Walters miniature. The Sinai illuminator carried the design over to the next headpiece, the one to II Thessalonians ${ }^{72}$. With few exceptions, the portraits in the Sinai Praxapostolos either agree with their counterparts in the Baltimore manuscript ${ }^{73}$, or have only a gesture, a pose, or an article of dress altered ${ }^{74}$. In the illustrations to Galatians and Hebrews, the illuminator of the Sinai Praxapostolos omitted the crowds listening to Paul preach, and in illustrating I Corinthians he left out Sosthenes. The sum of the minor changes made by the Sinai illuminator points to a sensibility: the author is repeatedly removed from any historical context. In the Sinai manuscript the author is generally alone, dressed in a nondescript himation, and doing nothing other than looking directly out at the beholder or stepping in the direction of the text. The change the Sinai illuminator introduced in the illustration of Hebrews expresses a Palaeologan interest. $\mathrm{H}$. Belting once noted the icon-like quality of Palaeologan illumination, a phenomenon he related to the increasing separation of the scribe and the illuminator and to the frequency with which the illuminator was a painter of icons $^{75}$. When, in the present instance, twelfth-century model and thirteenth-century adaptation are placed side by side, it becomes apparent that one result of the changes introduced by the later artist was a distancing of image from text. Separating Paul and each of his two companions in the illustration to II Thess was not merely an aesthetic choice $^{76}$. The illuminator severed the bond of joint authorship cited in II Thess 1:1, and in doing so he freed the figure from its dependent relationship on the word. The heavy frames only heighten the figures' independence. The differences represent another side of the phenomenon Belting observed. A final comparison confirms the change.

When the illuminator of the Walters Praxapostolos illustrated Hebrews, he did so by showing Paul preaching to a crowd. Uniquely, though, the illuminator alluded to the content of the letter through the depiction of Christ in the

\footnotetext{
74. Those with minor changes include: James, I and II Peter, I and III John, Jude, Philip, Colos, Phil.

75. H. Belting, Das illuminierte Buch in der spätbyzantinischen Gesellschaft, Heidelberg 1970, p. 14-17.

76. Der Nersessian, Praxapostolos, fig. 10; Weitzmann and Galavaris, Mount Sinai: Illuminated Greek Manuscripts, op. cit., fig. 374.
} 
heavens (fig. 19). The three points of the compositional triangle reflect the opening words of the Letter (1:1-2): «In many and various ways God spoke of old to our fathers by the prophets; but in these last days he has spoken to us by a son, whom he appointed heir of all things, through whom also he created the world». The illuminator of the Sinai Praxapostolos (fig. 20) removed the portrait of Christ, omitted the auditors, and turned Paul to face the beholder. The illuminator then created a headpiece like the one in the Baltimore manuscript at the start of I Thessalonians (fig. 2), only more elaborate. Into it he placed the Ancient of Days. The change may serve a theological point, but it may also simply reflect an intuitive response to the Saint's suggestive language. As the illustrations are compared in pairs through the two praxapostolos manuscripts one senses the creative mind of the Sinai illuminator at work changing a gesture or pose, but always beginning his creative leap with the Walters manuscript open before him.

The only headpiece that seems difficult to derive from the Walters manuscript occurs at the start of Romans; St. Paul appears bust-length in the middle of a block of ornament ${ }^{77}$. Portrayed in the corners of the field are Paul's disciple Timothy and three other figures cited in the Epistle as Paul's kinsmen (Rom 16:21): Lucius, Sosipater and Jason. The scale and complexity of the headpiece design may be attributed to the artist's desire to set the Pauline Epistles apart as an important subdivision of the Praxapostolos; similarly, the headpiece before Hebrews is more ornate than the simple bars and may likewise serve to mark a division within the collection. The design of the block with inset portrait busts is so common in Byzantine illumination that no reason exists to hunt for the illuminator's model.
The Sinai Praxapostolos enters the list of Byzantine manuscripts produced from works that survive. The illuminator adapted the illustrative contents to suit a different taste. The most intriguing aspect of the work relates to the consciousness of period style. The cursive text of the Sinai Praxapostolos is not that of the Baltimore manuscript, yet it resembles scripts of the twelfth century. Similarly, the ornament of three of the headpieces recalls twelfth-century work, contemporary with the later works of the group to which the Walters Praxapostolos belongs ${ }^{78}$. Even the large medial points occur in twelfth-century manuscripts like the Geneva Gospels and Basel New Testament (figs. 4, 6). The maker(s) of the Sinai manuscript combined ornament, script and illustration into a creation that suggests some consciousness of aesthetic unity.

The changes return us to the roughly mid-twelfth-century source, the Walters Praxapostolos, to appreciate how clear a message its artist could create out of compositions so unpromising in their simplicity. Knowing the other works produced by his circle opens the range of comparisons to books made for devotions and others for reference and study. For each type the illuminator found the most appropriate subjects and compositions. Although some vagueness surrounds the date when the manuscript was made and illustrated, it was unlikely to be at the start of the twelfth century, when several similarly illustrated manuscripts were made and dated. More plausible is a time around the middle of the century; this attribution, if sustained, demonstrates the continuity in the tradition of a group of scribes and illuminators active through the first half of the twelfth century.
77. Weitzmann and Galavaris, Mount Sinai: Illuminated Greek Manuscripts, op. cit. fig. 358.

78. See the patterns on fols. $254 \mathrm{v}, 283 \mathrm{v}(308 \mathrm{v}$ ), and 314 (fig. 20; and
Weitzmann and Galavaris, Mount Sinai: Illuminated Greek Manuscripts, op. cit. figs. 367,375 [381], 384). 


\title{
APPENDIX
}

\author{
Description of Cod. W 533 (Aland 1022)
}

The Praxapostolos is the work of two different periods. The biblical text (fols. 1-313), Euthalian apparatus, some of which is marginal, and illustration date from approximately the middle of the twelfth century. The lectionary apparatus, which consists of marginal notes in vermilion (ink that tends to orange) and comprehensive tables (fols 314-360), were added at least a century later. The twelfthcentury text was written by one scribe in forty gatherings, each numbered in the lower margin toward the gutter of the outside sheet. The scribe copied the text in a space roughly $11 \times 17 \mathrm{~cm}$; he wrote in brown ink and added the apparatus in carmine (red ink which shades to blue or purple). The apparatus included the $\alpha \varrho \chi \eta \dot{~ a n d ~} \tau \dot{\varepsilon} \lambda \mathrm{o} \varsigma$ of the lectionary, written within the text, and the occasional marginal note of the Euthalian apparatus. With two exceptions, the handwriting is regular throughout and is written in a careful, rounded script. The first exception is fols. 254-56, which were written by the scribe but in cursive. The second exception is fols. 267-268, which are later replacements for a lost bifolium. The late thirteenth-cen- tury lectionary in St. Catherine's on Mt. Sinai, cod. 275, appears to be a copy of Walters cod. 533 and it lacks the marginal apparatus with the exception of the occasional entry; this suggests that the tables (314-360) and marginal notes in Walters cod. 533 were added in the fourteenth century or later.

Each book of the biblical text is illustrated. The first miniature is badly abraded but can be generally restored with help of the miniature in the Sinai Praxapostolos (cod. 275, fol. 1: Weitzmann and Galavaris, Mt. Sinai: Illuminated Greek Manuscripts, fig. 341 [above note 19]) as supported by the Acts illustration in the related manuscript, Cod. Paris. suppl. gr. 1262 (fol. 35: Nees, Psalter at Harvard, fig. 7 [above note 8]). Three other illustrations are lost: the portrait to II Corinthians was carefully cut from fol. $195 \mathrm{v}$, the portrait to I Timothy was on a sheet now completely lost, and that to Titus is preserved (fol. 283) but has been completely repainted. The Sinai Praxapostolos is of questionable value in forming an impression of the lost scenes because its illuminator tended to simplify compositions.

\section{CONTENTS}

\section{1-89: Acts}

1 miniature (unpublished): marginal apparatus: chapt [er titles] 1-40: [H.F.] V[on] S[oden, Die Schriften des Neuen Testaments in ihrer ältesten erreichbaren Textgestalt, I/1, Berlin 1902, p.] 449-53; lect[ions] 1-51: VS 440; 89 col[ophon]: VS 299 [62].

Miniature: A block of ornament, now badly damaged, ran across the text column. A truncated circle in the middle contained the image of Christ flanked by his disciples. The miniature may be reflected by that on fol. 1 of Cod. Sinai. gr. 275 .

\section{9v-98: James}

89 portrait; $89-89 \mathrm{v}$ hyp[othesis]; VS 334 [134]; marginal apparatus: chapt: VS 457; lect 52-59: VS 456; 98 col: $\tau \dot{\lambda} \lambda \mathrm{o}$

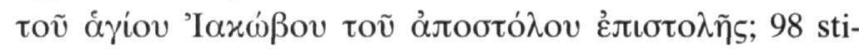
ch[ometry]: 242.

Miniature (fig. 10): James, an older man with grey beard, appears in episcopal dress, a blue tunic under a purple phelonion; he points with his right hand to a codex covered in gold and precious stones and edged in red.

\section{8-107v: I Peter}

98 portrait; 98-99 hyp: VS 335 [135]; marginal apparatus:

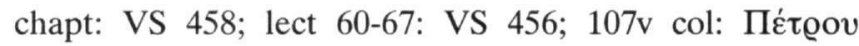

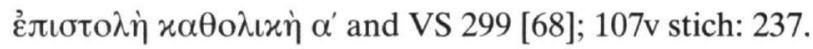

Miniature: Peter appears in ancient dress, a dark blue 
tunic and dusty purple himation. With his right hand he points to a gold covered codex held in the left.

\section{7v-114: II Peter}

$107 \mathrm{v}$ portrait; $107 \mathrm{v}-108 \mathrm{v}$ hyp: Vs 336 [137]; marginal

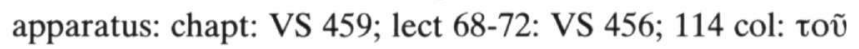

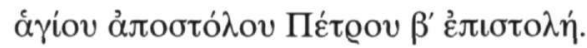

Miniature (Clark, Descriptive Catalogue [above note 5], pl. LX; Der Nersessian [above note 7], fig. 2): Peter wears a blue tunic under a brown himation. In his left hand he holds a scroll tied with red ribbons. The Apostle's glance and gesture direct the viewer to the beginning of the text.

\section{4-124v: I John}

114-115v hyp: VS 336-37 [137]; 116 portrait; marginal

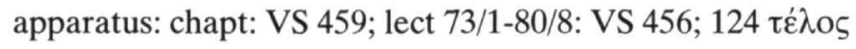

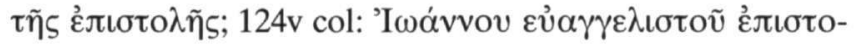

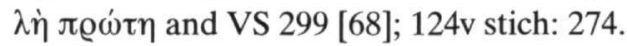

Miniature (fig. 1): John appears in ancient dress, a blue tunic under a dusty, olive-brown himation. The Apostle strides toward the text holding an open book; the illusion of movement is created by the pronounced bend at both knees.

\section{4v-126: II John}

124v-125 hyp: VS 337; 125 Chap 1, 2 (VS 460); 125 portrait; marginal apparatus: chapt: VS 460; lect 81: VS

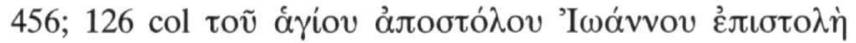

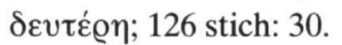

Miniature (Der Nersessian, fig. 3): Over a blue tunic, John wears a himation that is cream and dusty olive. $\mathrm{He}$ is depicted facing the beholder holding a closed codex.

\section{6-128: III John}

126 hyp: VS 338 [138]; 126-126v chapt 1-3: VS $460(1,10 ; 1$, 12; 1, 13); 127 portrait; marginal apparatus: lect 82/1: VS

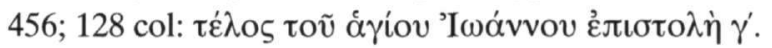

Miniature (Der Nersessian, fig. 4): John wears a blue tunic and dusty olive himation. He faces the text holding an open book but the stance fails to suggest movement. In this portrait he appears stocky; his weight falls on the left leg and the right is bent somewhat.

\section{8-131: Jude}

128-128v hyp: VS 338-339 [139]; 129 portrait; marginal apparatus: chapt: VS 460, lect 83/1-84/2: VS 456; $131 \mathrm{col}$ :

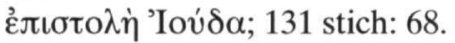

Miniature (Der Nersessian, fig. 5): Jude is depicted with black hair. Wearing a blue tunic under a dusty pink himation, he faces the beholder.

\section{1-163v: Romans}

131-133v hyp: VS 339-40 [140]; 133v portrait; marginal apparatus: chapt: VS 462, lect 85/1-129/45: VS 461; $163 \mathrm{v}$ col: VS 300 [70+72]; 163v stich 920.

Miniature (Der Nersessian, fig. 6): Paul has black hair and beard. He stands facing the beholder and wearing a blue tunic and a dusty blue himation. With his left hand he balances a red-covered codex; his right hand is extended far from his body in a grand gesture.

\section{3v-194v: I Corinthians}

163v-165 hyp: VS 340-41; 165 portrait; marginal apparatus: chapt: VS 463; lect 130/1-177/47: VS 461; 194v col: VS 300 [70+72]; 194v stich 870 .

Miniature (fig. 13): In this double portrait, the illuminator extended the frame into the left margin. At the left stands Paul, wearing a blue tunic under a blue-green himation. In his left hand he holds a tied roll and with his right he gestures in speech to the other man, at whom he glances. Next to Paul is Sosthenes, mentioned in the first verse as the letter's co-author. $\mathrm{He}$, too, is dressed in ancient costume, a blue tunic and dusty pink himation.

\section{4v-216: II Corinthians}

194v-196v hyp: VS 341-42 [147]; 195 mutilated: portrait carefully cut from verso; marginal apparatus: chapt: VS 464, lect 178/1-209/31: VS 461; 216 col: VS 300 [70+72]; 216 stich 590.

\section{6-226v: Galatians}

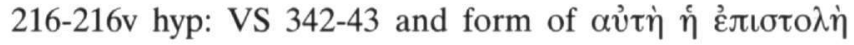

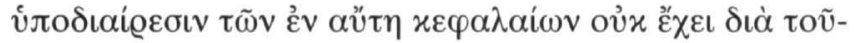

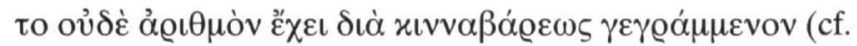

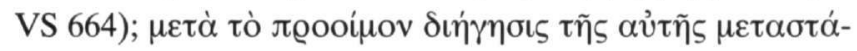

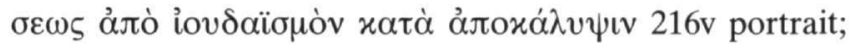
marginal apparatus: chapt: VS 464-65; lect 210/1-227/17: VS 461; 226v col: VS 300 [70+72]; 226v stich: 293.

Miniature (fig. 12): Paul, dressed in blue tunic and green- 
blue himation, turns and extends his right arm to an audience of men, the Galatians. The crowd consists of three representatives; reading from left to right, they are a middle-aged man wearing a scarlet robe and white shawl; an older, bald man with beard and a beardless youth with a blue tunic and red himation.

\section{6v-238: Ephesians}

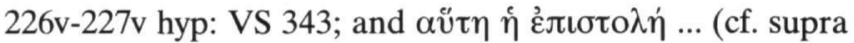
$216 \mathrm{v}) ; 227 \mathrm{v}$ portrait; marginal apparatus: chapt: VS 465 ; lect 228/1-248/21: VS 461; 238 col: VS 300 [70+72]; 238 stich: 312.

Miniature: Paul wears a blue tunic and green himation. He is posed frontally, his free leg (right) pulled off to the side.

\section{8v-246v: Philippians}

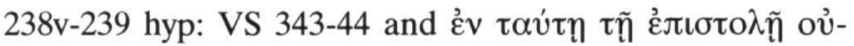

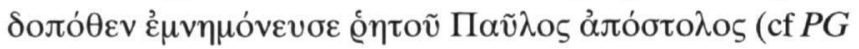

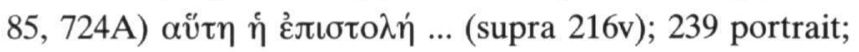
marginal apparatus: chapt: VS 465; lect 249/1-262/14: VS 461; 246v col: VS 300 [70+72]; 246v stich: 208.

Miniature: (fig. 16): A two-figure group that again reflects the authorship revealed in the Letter's salutation (1:1). At the left is Timothy in episcopal dress, a blue tunic and purple phelonion; he has black hair and a short black beard. Paul stands at the right in ancient dress, a blue tunic and green himation. Both authors turn toward the center of the composition; they look and extend their hands upward, as if in prayer to the heavens; the pose may have been prompted by $1: 3$.

\section{6v-254v: Colossians}

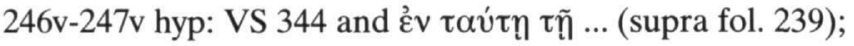
$247 \mathrm{v}$ portrait; marginal apparatus: chapt: VS 465-66; lect 263/1-277/12; 254v col: VS 300 [70+72]; 254v stich 208.

Miniature: The miniature shows Paul and Timothy in the same dress and poses as in the miniature on fol. 239.

\section{4v-261v: I Thessalonians}

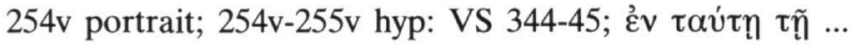

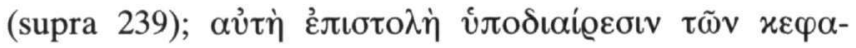

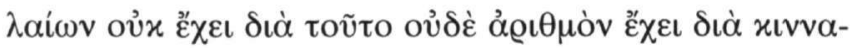

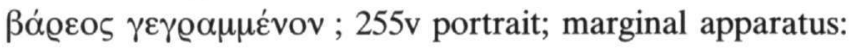

chapt: VS 466; lect 278/1-288/8: VS 461; 261v col: VS 300 [70+72]; 261v stich: 193.

First miniature (254v): Paul, wearing a blue tunic and a dusty green himation extends his right arm in address to a group of men, all in tunics and most beardless; the artist carefully varies the colors of each man's dress, using, from left to right, red, green, blue, salmon, purple.

Second miniature (255v, fig. 2): The miniature breaks the format but not style. Three portrait roundels contain portraits of the Letter's joint authors. At the left is Silas (Silvanus) in ancient dress, a green tunic and pink himation. In the center appears Paul in blue tunic and green himation. At the right is Timothy, who wears a purple phelonion.

\section{1v-265v: II Thessalonians}

$261 \mathrm{v}-262 \mathrm{v}$ hyp: VS $345-46 ; 262 \mathrm{v}$ portrait; marginal apparatus: chapt: VS 466; lect 289/1-293/5: VS 461; 265v col: VS 300 [70+72]; 265v stich 107.

Miniature (Der Nersessian, fig. 10): A three-figure composition that has the illuminator invading the left margin. The figures are Timothy, Silas and Paul. Timothy wears a purple phelonion over a blue tunic, Silas a blue tunic and slightly pink, light brown himation, and Paul a blue tunic and gren himation. Silas and Paul turn slightly to one another; Paul holds a red covered codex and the other two men look toward him. Note the shape of the text, written accommodate a more complex initial.

265v-275: I Timothy; fols. 267, 268 later replacement (keph 6-17; I Tim 1:1-19).

265v-266v hyp: VS 347-48; 266v-267 chapt: VS 467; marginal apparatus: lect [294/1]-307/14: VS 461.

\section{5-282: II Timothy}

275-276 hyp: VS 348-49; 276-276v chapt: VS 467-68; 276v portrait; marginal apparatus: lect 308/1-317/10: VS 461.

Miniature: Paul stands facing the beholder; the author wears a blue tunic and a warm brown himation.

\section{2-286v: Titus}

282-283 hyp: VS 349; 283 chapt: VS 468; 283 portrait; marginal apparatus: lect 318/1-322/6: VS 461.

Miniature: The miniature shows a bust-length figure, but it has been entirely restored. 
286v-288: Philemon

286v hyp: VS 349; 286v-287 chapt: VS 468; 287 portrait; marginal apparatus: lect 323/1: VS 461.

Miniature (Der Nersessian, fig. 11): Paul stands at the left wearing a blue tunic and deep purple himation. $\mathrm{He}$ is turned nearly in profile as he raises his right hand to speak to Timothy, posed frontally but turning his head in Paul's direction. Timothy holds a codex and is dressed in a blue tunic and brownish purple phelonion.

288v-313v: Hebrews

288v-289 hyp: VS 346; 289-290v chapt: VS 468-69; 291 portrait; marginal apparatus: lect 324/1-359/37: VS 461. 313 end of Hebrews. End of twelfth-century text.

Miniature (fig. 19): A gigantic figure of Paul, wearing a deep purple tunic and dusty, thinned purple himation, holds a scroll in his left hand as he raises his right in address to a group of Jews. Paul's face is flaked. The Jews are all men, old, middle-aged and young; they wear single colored garments in, from left to right, red, dusty purple, blue, and bluish purple. Paul speaks of Christ, who is represented bust-length in the heavens.

314-360v: lectionary tables, added at a later date. 